\title{
Simulating climate change impact on soil erosion using RUSLE model - A case study in a watershed of mid-Himalayan landscape
}

\author{
Surya Gupta and Suresh Kumar* \\ Indian Institute of Remote Sensing, Indian Space Research Organisation, \\ 4 Kalidas Road, Dehradun 248001 , India. \\ *Corresponding author.e-mail: suresh_kumar@iirs.gov.in
}

\begin{abstract}
Climate change, particularly due to the changed precipitation trend, can have a severe impact on soil erosion. The effect is more pronounced on the higher slopes of the Himalayan region. The goal of this study was to estimate the impact of climate change on soil erosion in a watershed of the Himalayan region using RUSLE model. The GCM (general circulation model) derived emission scenarios (HadCM3 A2a and B2a SRES) were used for climate projection. The statistical downscaling model (SDSM) was used to downscale the precipitation for three future periods, 2011-2040, 2041-2070, and 2071-2099, at large scale. Rainfall erosivity $(R)$ was calculated for future periods using the SDSM downscaled precipitation data. ASTER digital elevation model (DEM) and Indian Remote Sensing data - IRS LISS IV satellite data were used to generate the spatial input parameters required by RUSLE model. A digital soil-landscape map was prepared to generate spatially distributed soil erodibility $(K)$ factor map of the watershed. Topographic factors, slope length $(L)$ and steepness $(S)$ were derived from DEM. Normalised difference vegetation index (NDVI) derived from the satellite data was used to represent spatial variation vegetation density and condition under various land use/land cover. This variation was used to represent spatial vegetation cover factor. Analysis revealed that the average annual soil loss may increase by $28.38,25.64$ and $20.33 \%$ in the 2020s, 2050s and 2080s, respectively under A2 scenario, while under B2 scenario, it may increase by $27.06,25.31$ and $23.38 \%$ in the $2020 \mathrm{~s}, 2050 \mathrm{~s}$ and $2080 \mathrm{~s}$, respectively, from the base period (1985-2013). The study provides a comprehensive understanding of the possible future scenario of soil erosion in the mid-Himalaya for scientists and policy makers.
\end{abstract}

\section{Introduction}

The Himalayan region is afflicted with a serious problem of soil erosion and the rivers flowing through this region transport heavy load of sediments which include large amounts of soil nutrients (Sharma et al. 1991). It adversely affects the crop productivity, water quality, hydrological system and the environment (Lal 1998). Soil erosion rates may be expected to change in response to climate change, primarily due to the change in the rainfall erosivity (Nearing 2001). Several studies have shown a significant impact of climate change on soil erosion (Michael et al. 2005; Neal et al. 2005; Li et al. 2011; Segura et al. 2014). Therefore, it is important to quantify the impact of climate change on erosion for understanding their environmental impacts as well as for food security (Lal 2005; Pimentel 2006).

Keywords. Climate change; soil erosion; statistical downscaling model (SDSM); revised universal soil loss equation (RUSLE). 
Modelling approaches are commonly used to simulate climate change impact on hydrology, soil erosion and crop yield (Priya and Shibasaki 2001; Li et al. 2011). Universal soil loss equation (USLE) (Wischmeier and Smith 1978) and the revised universal soil loss equation (RUSLE) were developed in the early 1990s (Renard et al. 1991) and are commonly used empirical models to assess soil erosion risk. RUSLE has been the most widely used model to predict soil erosion (Van Rompaey et al. 2001; Pruski and Nearing 2002; Jiang et al. 2012). The RUSLE model integrates six factors related to rainfall erosivity $(R)$, soil erodibility $(K)$, slope steepness $(S)$, length factor $(L)$, vegetation cover factor $(C)$ and management factor $(P)$. Advances in remote sensing and GIS and their integration with erosion models had improved the spatial soil erosion risk assessment (Adediji et al. 2010). Satellite data provide spatial data for several input parameters of erosion models. Land use classification is often used to map vegetation cover types using remote sensing data. Spectral vegetation index such as Normalized Difference Vegetation Index (NDVI) is also used as an indicator of vegetation cover (Jain and Goel 2002; Thiam 2003). NDVI was used for the estimation of C-factor to define vegetation cover factor (De Jong et al. 1999). Readily available soil maps are used to compute the soil erodibilty factor, but in most cases, soil maps are not available at appropriate scale. Therefore, generating digital soil-landscape map employing clorept model (Jenny 1941) by integrating landform, topography and LULC types provides an alternative to map spatial variability of soils at an appropriate scale. Availability of global digital elevation models (DEMs) had facilitated retrieval of topographic parameters more precisely and spatially (Zhang et al. 2008). Integration of RUSLE with GIS has been reviewed to be a successful approach for estimating quantitative erosion and have shown significantly better results (Lu et al. 2004; Prasannakumar et al. 2011). Studies indicate that the spatial data inputs provided to the model using remote sensing (RS) techniques have increased the accuracy of RUSLE model in soil risk assessment (Kouli et al. 2009; Kumar and Khushwaha 2013).

Rainfall-runoff erosivity $(R)$ is one key climate factor that controls water erosion. It is defined as a product of storm kinetic energy and maximum 30-min intensity (EI30). When other factors are constant, soil losses from rainfall are directly proportional to the rainfall erosivity (Arnoldous 1978). Quantifying the effects of climate change-induced erosivity change is important for identifying critical regions prone to soil erosion under a changing environment. Change in rainfall erosivity was found to be a major effect of climate change on soil erosion (Nearing et al. 2004; Zhang et al. 2005; Shiono et al. 2013), which represents the change in intensity and frequency of rainfall.

All general circulation models (GCMs) have reported that globally average temperature, rainfall and intensity of rainfall events will increase in future (IPCC 2001). Available estimates in literature also suggest an increase in the rainfall intensity in the 21st century over most regions in India. Precipitation increases by $1.2-2.4 \%$ by 2030s under different RCP scenarios and by 3.5$11.3 \%$ by $2080 \mathrm{~s}$, relative to the pre-industrial base. Precipitation is projected to increase almost all over India except for a few regions in short-term projections (2030s) (Kumar et al. 2006). Under the projected climate change, several studies have revealed an increase in soil erosion risk in the future (Boardman and Favis-Mortlock 1993; SWCS 2003). Global data (CMIP3 and CMIP5) are available at coarse resolution $\left(2.75^{\circ} \times 3.75^{\circ}\right)$ and it is impossible to use them directly for fine-scale environmental studies (Hansen and Indeje 2004; Zhang and Liu 2005). Therefore, dynamic downscaling and statistical downscaling approaches are commonly used to downscale the coarse resolution data to fine resolution data (Wilby 2004). Dynamic downscaling uses regional climate model (RCM) to downscale the climate data at regional scale, but is a costly approach and requires a super computer. However, statistical downscaling is easier to implement and is quite cost effective.

Climate change is expected to impact soil erosion in the Himalayan region. Spatially-explicit predictions of future erosion rates under changing climatic conditions are not studied in the Himalayan region. It needs to be evaluated for better conservation planning. Study on impacts of climate change on soil erosion rate and risk area in the watershed is required for conserving soil against erosion. This information can be transferred to agricultural organisations and policy makers, so that the policies can be framed according to the predicted results and thus, the farmers can take appropriate measures to conserve soil and water in future. The objective of the present study is to evaluate the potential impacts of HadCM3 projected climate change on soil erosion at a large scale during three periods in a watershed located in the mid-Himalayan region. Statistical downscaling model (SDSM) was employed to downscale HadCM3 global projected scenario rainfall to point scale (weather station). This projected rainfall data was used to compute projected rainfall erosivity and further estimate the soil erosion employing RUSLE model over the three periods: 2020 (20112040), 2050 (2041-2070), 2080 (2071-2099). The study will provide a preliminary evaluation of the potential impact of future climate change on soil erosion in the mid-Himalayan region. 


\section{Study area and data description}

\subsection{Study area}

The study was carried out in a watershed covering an area of $380 \mathrm{~km}^{2}$ located mid-Himalaya of Tehri Garhwal district, Uttarakhand, India. The elevation in the watershed ranges from 500 to $2500 \mathrm{~m}$ above MSL. It lies between $78^{\circ} 17^{\prime} 47^{\prime \prime}-$ $78^{\circ} 29^{\prime} \mathrm{E}$ longitudes and $30^{\circ} 13^{\prime} 26.4^{\prime \prime}-30^{\circ} 24^{\prime} 21.59^{\prime \prime} \mathrm{N}$ latitudes (figure 1). The geological set-up is very complex due to the repetitive tectonic disturbances. A group of regionally metamorphosed rocks known as central crystalline are present in the central Himalayas. The study area is characterised as humid sub-tropical. The average annual (1985-2013) maximum and minimum temperatures are $9.93^{\circ}, 19.21^{\circ} \mathrm{C}$, respectively, and the average annual rainfall is $1246.3 \mathrm{~mm}$. More than $60 \%$ rain occurs during the months of June-September. Soils are moderately deep, well drained, dark brown to dark yellowish brown, gravelly loam (typic Udorthents) associated with deep, well drained, dark brown to brown, sandy loam to loam with developed horizons. Soil depth varies from 20 to $80 \mathrm{~cm}$. Forest soils are rich in organic carbon. Coarse fragments vary from 20 to $70 \%$. The manning's roughness coefficient has been taken as 0.05 , considering the boulder beds and hilly terrain of Himalaya (Joshi et al. 2015). The major land use/land cover classes are croplands, dense and open forests of pine, scrublands and barren lands. Paddy (Oryza sativa) and jhangora (Echinochloacolona) are major crops grown in Kharif (summer), whereas wheat (Triticum aestivum) is cultivated during Rabi (winter) season.

\subsection{Data preparation}

\subsubsection{Data used}

Indian remote sensing satellite (Resourcesat-2) multispectral LISS IV data (spatial resolution of $5.8 \mathrm{~m}$ ) acquired on 14 October, 2012 was used to generate the NDVI and LISS III data for land use/ land cover map, respectively were used to generate vegetation cover types. ASTER DEM (spatial resolution of $30 \mathrm{~m}$ ), downloaded from www. earthexplorer.usgs.gov, was used to derive topographic (slope length and steepness) parameters.

\subsubsection{Software used}

ERDAS Imagine software, version 2014, was used for image processing, while the GIS analysis was carried out using ArcGIS v.10.1 software in order to generate the digital coverage of various input parameters of the erosion model.

\subsubsection{Field data collection}

Surface soil samples $(0-20 \mathrm{~cm})$ were collected from various soil-landscape units. Twenty soil-landscape units were identified in the watershed. A transect was selected for soil sampling and the corresponding GPS locations of sample sites were recorded. Soil samples were analysed for soil texture, organic matter, soil structure and permeability. These samples were processed and analysed for soil texture (sand, silt and clay) using Bouyoucos hydrometer method (Sheldrick and Wang 1993), while soil organic carbon (SOC) was estimated using the Walkley-Black method (Nelson and Sommers 1996). Soil structure and other characteristics were also recorded during the field survey. Information of land use/land cover (LU/LC) was collected and the geographic location was recorded using GPS. Land management practices followed by farmers in the watershed were also collected to define management practice factor (P-factor).

\section{Methodology}

\subsection{Downscaling of HadCM3 global rainfall (precipitation) data using SDSM model}

Global climate data from the Hadley Centre's Coupled Model (HadCM3), one of the models among the CMIP3 experiment, have been also downscaled by a high-resolution regional climate model for India under the 'Providing Regional Climate for Impact Studies (PRECIS)' project (Kumar et al. 2006). HadCM3 model (Hadley GCM 3) data are very popular GCM data which are used by many researchers in the world (Collins et al. 2001; Houghton et al. 2001; Hassan et al. 2014), as well as for Indian condition (Kannan and Ghosh 2011; Raje and Mujumdar 2011; Meenu et al. 2012).

CMIP5 models are generally of a higher resolution compared to their CMIP3 counterparts. Different CMIP5 model outputs are available on different spatial scales. These outputs for both historic and climate projections are then regridded to a common spatial scale of $0.5 \times 0.5 \mathrm{deg}$ resolution. Analysis of the CMIP5 models indicated that the CMIP3 simulations are of comparable quality to the CMIP5 simulations for temperature and precipitation at regional scales (Flato et al. 2013). Knutti et al. (2013) evaluated CMIP3 and CMIP5 models data for hydrologic simulations and observed similar to a comparable analysis of CMIP5 runs since most models in CMIP5 are 'strongly tied to their predecessors'. Zhang et al. (2016) observed CMIP5 historical simulations similar to those obtained with the CMIP3 simulations for climate over North America. They found little-to-no improvement in 


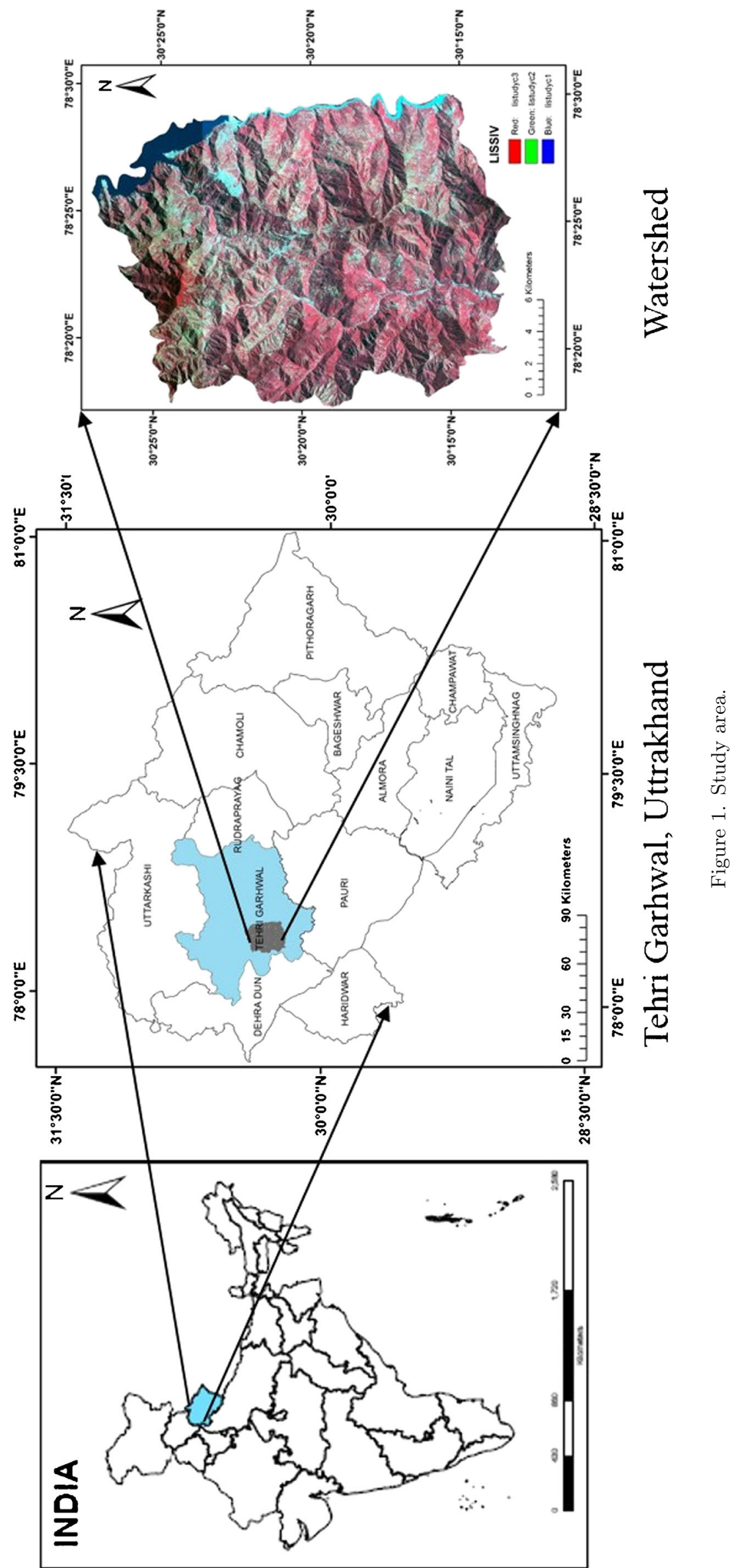


regional predictability to result from the substantial model development and improvement between CMIP3 and CMIP5 climate models.

SDSM is one of the most widely used statistical models to downscale global climate data (Mahmood and Babel 2012; Meenu et al. 2012; Daba et al. 2013). It is a hybrid model that combines the multiple linear regression and stochastic weather generator (Gagnon et al. 2005). However, the output of GCM and SDSM does not provide the detailed information of precipitation (Zhang et al. 2010). A relationship between precipitation and rainfall erosivity has been developed to calculate the rainfall erosivity from GCM data (Sun et al. 2002; Plangoen et al. 2013). Estimation of future climate change provided by GCMs does not provide the type of detailed rainfall information needed to directly calculate predicted $R$-factor changes. Hence, the statistical relationship between monthly and annual precipitation and the $R$-factor may be used to analyse the GCMs output relation to erosivity changes (Nearing 2001). Using this relationship, precipitation output from GCMs can be analysed for trends in $R$-factor changes.

In the study, historical daily climate data of maximum temperature, minimum temperature and rainfall amount was obtained from the Department of Meteorology, Uttarakhand University of Horticulture and Forestry for Ranichauri weather station for the period 1985-2001. The weather station is located in the middle of the study area. The GCM data of HadCM3 - a coupled atmosphere-ocean GCM developed at the Hadley Centre UK, of H3A2 and H3B2 IPCC emission scenarios of HadCM3 - were used in the study. The SDSM model and scenario data for the periods of 1961-
2001 and 1961-2099 were downloaded from the website: web.archive.org/web/20150922205713/http: //www.cics.uvic.ca/scenarios/sdsm/select.cgi. Daily GCM data was downscaled using SDSM. Multiple linear regression equations were developed for each perdictand (weather station data at local point scale) with a number of predictors (GCM data). The model could be run either monthly, annually or seasonally. The annual model generates one equation for 12 months (annually), whereas the monthly model generates 12 equations, one equation for each month. In this study, the SDSM model was specified to run on an annual basis for ease in calibration of the model, since it gave better output than the monthly basis (Mahmood and Babel 2012).

The available climate dataset (perdictand) from 1985 to 1993 (9 yrs) of the weather station was used to calibrate the model for rainfall (precipitation). The climate data from 1994 to 2001 (8 yrs) of the weather station was used for validation. Once the model accuracy was found to be satisfactory, it was used to downscale the HadCM3 GCM data for the baseline/current period (1961-1990) and for the three future periods; the 2020s (20102039), the 2050s (2040-2069), and the 2080s (20702099), using a weather generator. A methodology for downscaling is described in figure 2 .

\subsection{RUSLE model description}

RUSLE is an empirical model that is used worldwide to estimate the annual soil loss and intensity of soil erosion. RUSLE uses the same empirical principles as USLE, but includes numerous improvements in the computation of various

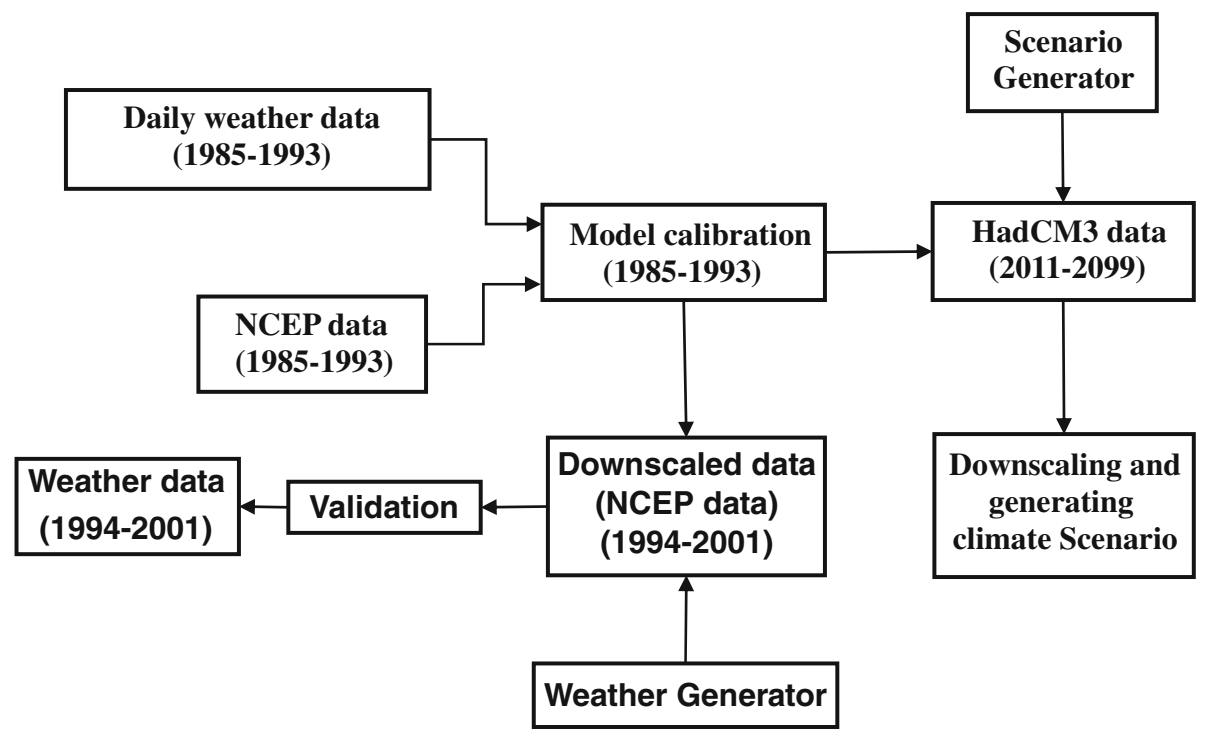

Figure 2. Methodology of SDSM model. 
factors. The RUSLE has been widely used for both agricultural and forest watersheds to predict the average annual soil loss by introducing improved means of computing the soil erosion factors (Wischmeier and Smith 1978; Renard et al. 1997). Application of the RUSLE model has the advantages as its data requirements are not too complex or unattainable within a developing country; it is compatible with a geographic information system (GIS) and it is easy to implement and understand from a functional perspective (Wischmeier and Smith 1978). Integration of RUSLE with GIS makes it a more powerful tool in soil erosion assessment (Prasannakumar et al. 2011, 2012). Over wider geographic areas and larger varieties of agricultural systems, there is a tendency for the USLE and the RUSLE to overpredict low average annual soil losses and to underpredict high average annual soil losses (Risse et al. 1993; Tiwari et al. 2000). RUSLE model considers the factors of climate (rainfall erosivity), soil (soil erodibility), topography (slope length and steepness) and vegetation cover (vegetation cover factor and management factor). These variables vary with space and time. RUSLE model is described as:

$$
A=R * K * L S * C * P,
$$

where $A\left(\mathrm{t} \mathrm{ha}^{-1} \mathrm{y}^{-1}\right)$ is the annual average soil loss per year; $R$ ( $\mathrm{m} \mathrm{tha-} \mathrm{cm}^{-1}$ ) is the rainfall erosivity factor, $K\left(\mathrm{t} \mathrm{ha}^{-1} \mathrm{R}^{-1}\right)$ is the soil erodibility factor, $L S$ (dimensionless) is the topographic factor, $C$ (dimensionless) is the land cover factor and $P$ (dimensionless) is the soil conservation or prevention practices factor. The details of the above-mentioned factors and generation of spatial data layers are discussed below.

\subsection{Generation of model input parameters as spatial data layers}

\subsubsection{Rainfall erosivity ( $R$ ) factor}

Rainfall erosivity $(R)$ indicates the effect of rainfall intensity and frequency on soil erosion. $R$ is the product of storm kinetic energy and maximum 30-min intensity (EI30) (Arnoldous 1978). When other factors are constant, soil losses from rainfall are directly proportional to rainfall erosivity. It requires a long-term data of rainfall amount and its intensity. However, in most of the areas, these data are unavailable. $R$ factor for the watershed was computed using the relationship developed by Singh et al. (1981) based on average annual/ seasonal rainfall.

$$
Y=81.5+0.375 * X(r=0.90)(340<X<3500),
$$

where $Y$ is the average annual erosion index and $X$ is the average annual/seasonal rainfall.

For applying above equation, the seasonal rainfall data is required. Therefore, daily data of rainfall from 1985 to 2013 was collected and average rainfall data for a weather station, located in the watershed.

The above rainfall erosivity equation was used for predicting rainfall erosivity for current as well as future scenarios (A2 and B2). For this study, HadCM3 GCM output was used for predicting precipitation for future scenarios. The equation was applied assuming the similar behaviour of rainfall and rainfall erosivity in future. Therefore, the equation was applied for each year of rainfall data from 1985 to 2099, and 30 yrs average was considered to examine Nearing (2001) also used the output of GCMs and statistical relationships on erosivity values from the RUSLE model to compute climate change induced alterations of the erosive power of rainfall in USA.

\subsubsection{Soil erodibility (K) factor}

Soil erodibilty is a measure of the susceptibility of soil particles to detachment that is related to the soil texture, structure, permeability and soil organic matter content. Soil erodibility factor $(K)$ is calculated for each soil landscape unit.

Dominant land use/land cover classes were mapped using visual interpretation of satellite data of the area in Arc-GIS 10.1. The major aspect classes, north and south were classified using DEM. The landform map was prepared by using the topographic positioning index (TPI) values and thereafter was classified into five landform elements: hill top, upper slope, middle slope, lower slope and valley. Landform elements, LU/LC and aspect maps were intersected to arrive at 30 soil landscape units in the watershed. These 30 classes were reduced to 15 classes based on the area representations. Soillandscape units with minor areas were merged with dominant landscape units.

Three soil samples from each landscape unit were collected and analysed in a laboratory for soil texture and soil organic matter. The $K$ values for each landscape unit were computed using the following equation proposed by Wischmeier and Smith (1978):

$$
\begin{aligned}
K= & 2.8 * 10^{-7} M^{1.14}(12-O M)+4.3 * 10^{-3}(S-2) \\
& +3.3 * 10^{-3}(P-3),
\end{aligned}
$$

where $K$ is the soil erodibility factor in $\mathrm{t}^{-1} \mathrm{ha}^{-1} \mathrm{R}$, $M$ is the (percentage of very fine sand + percentage silt $) \times(100-$ percentage clay $), O M$ is the percentage of organic matter, $S$ is the code according to the soil structure (very fine granular $=1$, fine granular $=2$, coarse granular $=3$, lattice 
or massive $=4)$, and $P$ is the code according to the permeability/drainage class (fast $=1$, fast to moderately fast $=2$, moderately fast $=3$, moderately fast to slow $=4$, slow $=5$, very slow $=6$ ).

Average of $K$-values for each landscape unit was calculated and $K$-attribute map was generated using soil-landscape map in GIS.

\subsubsection{Slope length (L) and steepness (S) factor}

Slope length and steepness affect the erosive power of water. If the length and steepness of slope are more, the erosion will be high and vice versa. It can be estimated through field measurements or can be derived from digital elevation model (DEM). $L S$ equation has been developed to generate topographic factor map based on DEM (Moore and Wilson 1992). Slope gradient $(S)$ and slope length $(L)$ are combined to form a single factor known as the topographic factor $(L S)$. The equation used to determine $L S$-factor was recommended by Mitasova et al. (1996) given as:

$$
\begin{aligned}
L S= & \text { Pow }\left([\text { Flow Acc }] * \frac{\text { resolution }}{22.1,0.6}\right) \\
& * \text { Pow }\left(\left(\frac{\text { Sin }[\text { slope gradient }] * 0.01745}{0.09}\right), 1.3\right)
\end{aligned}
$$

ArcGIS software was used to derive the $L$ and $S$ values of each pixel. Slope degree was determined using spatial analyst tool of the ArcGIS. Slope length was estimated using hydrology tool of spatial analyst tool, using which the flow accumulation map was also generated. The flow accumulation map denotes the number of pixels receiving overload flow. This map was further used to calculate slope length $(l)$ for each pixel in meters.

\subsubsection{Vegetation cover (C) factor}

Vegetation cover factor was assigned for various land use/land cover types (Millward and Mersey 1999; Durigon et al. 2014). It is defined as the ratio of soil loss from the land cropped under specific conditions to the corresponding loss from cleantilled, continuous fallow land (Wischmeier and Smith 1978). Several studies assigned crop cover (vegetation cover) $C$ factor based on land use/land cover types (Kumar and Khushwaha 2013). However, in these studies, the variation in vegetation density and condition was not accounted. Thus, in the present study, vegetation index derived from remote sensing data such as NDVI was used to account for the variation in vegetation condition in forests and scrublands (Reusing et al. 2000; Lin et al. 2002, 2006). NDVI was computed for each pixel of the study area using following equation:

$$
\mathrm{NDVI}=(\mathrm{NIR}-\mathrm{Red}) /(\mathrm{NIR}+\mathrm{Red}),
$$

where Red and NIR stand for the spectral reflectance measurements acquired in the visible (red) and near-infrared regions, respectively. NDVI values range from -1.0 to 1.0 , where higher values are for vegetation and lower ones are for other common surface materials (bare soil, water). Bare soil is represented with NDVI values closest to 0, while water bodies are represented with negative values. IRS LISS IV satellite data was used to generate NDVI image.

NDVI has been used to compute $C$ factor (Zhou et al. 2008; Kouli et al. 2009), being an indicator of vegetation density and its condition.

$$
C=\exp \left[-\alpha \frac{\mathrm{NDVI}}{\beta-\mathrm{NDVI}}\right]
$$

where $\alpha$ and $\beta$ are unitless parameters that determine the shape of the curve relating to NDVI. The values of these parameters were taken to be 2 and 1, respectively (Van der Knijff et al. 2000). This approach provided better results than assuming a linear relationship (Van der Knijff et al. 2000) of NDVI and $C$ value.

\subsubsection{Conservation practice $(P)$ factor}

The conservation practice factor ( $P$-factor) is the soil-loss ratio with a specific conservation practice to the corresponding soil loss with up and down slope tillage (Renard et al. 1991). In the present study, $P$-factor values were assigned to various types of land use/land cover types, considering the management practices being adopted in these cover classes. The values of $P$-factor range from 0 to 1 , in which the highest value was assigned to areas with no conservation practices (scrubland, waste land), while the minimum values corresponded to built-up land and dense forest (Renard et al. 1997). In the watershed, agricultural field was terraced and well bunded. The riser of terrace field was stabilised by grasses and with stones/boulders at many places. Field bunds were regularly being maintained in pre-monsoon season. The $P$ factor values assigned to LU/LC types are given in table 5 .

\subsubsection{Predicting soil loss and erosion risk assessment}

RUSLE model input parameter $(R, K, L S, C$, and $P$ ) maps were prepared in GIS to estimate spatial potential soil erosion rates. Predicted soil erosion rate was classified into soil erosion risk classes of very slight $\left(0-5 \mathrm{t} \mathrm{ha}^{-1} \mathrm{yr}^{-1}\right)$, slight $\left(5-10 \mathrm{t} \mathrm{ha}^{-1} \mathrm{yr}^{-1}\right)$, 
moderate (10-20 t ha $\left.{ }^{-1} \mathrm{yr}^{-1}\right)$, moderately high (20-40 t ha $\left.\mathrm{yr}^{-1}\right)$, severe $\left(40-80 \mathrm{t} \mathrm{ha}^{-1} \mathrm{yr}^{-1}\right)$ and very severe $\left(>80 \mathrm{t} \mathrm{ha}^{-1} \mathrm{yr}^{-1}\right)$ risk classes.

\subsubsection{Validation of model}

A total of 20 field sites were observed for field features to characterise erosion classes. Thus, soil samples were collected along with topographic parameters (length and steepness) and vegetation cover and management practices of the sites and soil loss were estimated using RUSLE model. A total of 20 sites were selected; of these seven sites were in the forest and nine sites were in the cropland, while four sites were in the scrubland. The model predicted soil erosion risk classes were validated with model calculated erosion risk of observed sites. The average soil loss of each site $(3 \times 3$ pixel $)$ was extracted from RUSLE predicted soil erosion map. This soil loss and observed sites estimated soil loss were analysed for the coefficient of determination and RMSE to validate the accuracy of results.

\section{Results and discussion}

\subsection{Downscaling of climate data}

Twenty ensemble members were used to simulate the daily data of rainfall. The coefficient of determination $\left(r^{2}\right)$ and RMSE were computed to assess the accuracy of a model. Results had shown that, in case of rainfall, $r^{2}$ and RMSE for NCEP, A2 and $\mathrm{B} 2$ are $0.80,0.71$ and 0.76 and 27, 50 and 35.8 $\mathrm{mm}$, respectively. Low RMSE values of precipitation data showed good performance in the downscaling of data. The study also revealed that the average annual rainfall of the area may increase by $33.3,30.02$ and $23.79 \%$ for A2, while 31.67 , 29.60 and $27.87 \%$ for B2 emission scenario in 2020 s, 2050 s and 2080s, respectively. From figure 3(a, b), it is evident that precipitation will increase $(33.3 \%)$ from the base period until 2020s. But, it may get reduced by $3-10 \%$ after 2020 . Kumar et al. (2006) predicted an increase in rainfall from the baseline period (1961-90) to the end of 21st century ranges between 15 and $40 \%$ among the models. Most models predicted an enhanced precipitation

\section{Change in precipitation for H3A2 scenario}

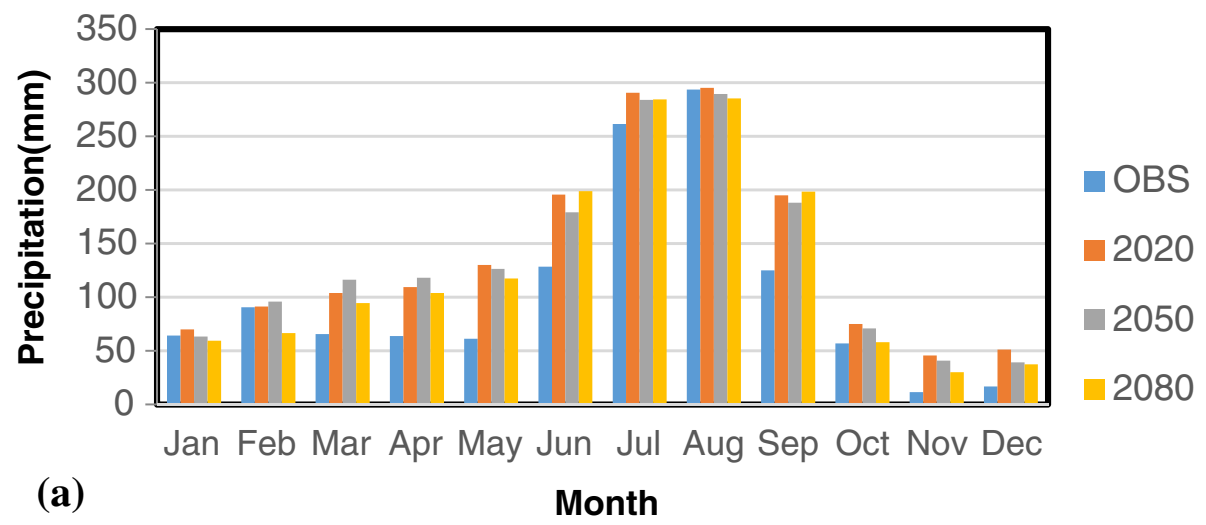

Change in precipitation for H3B2 scenario

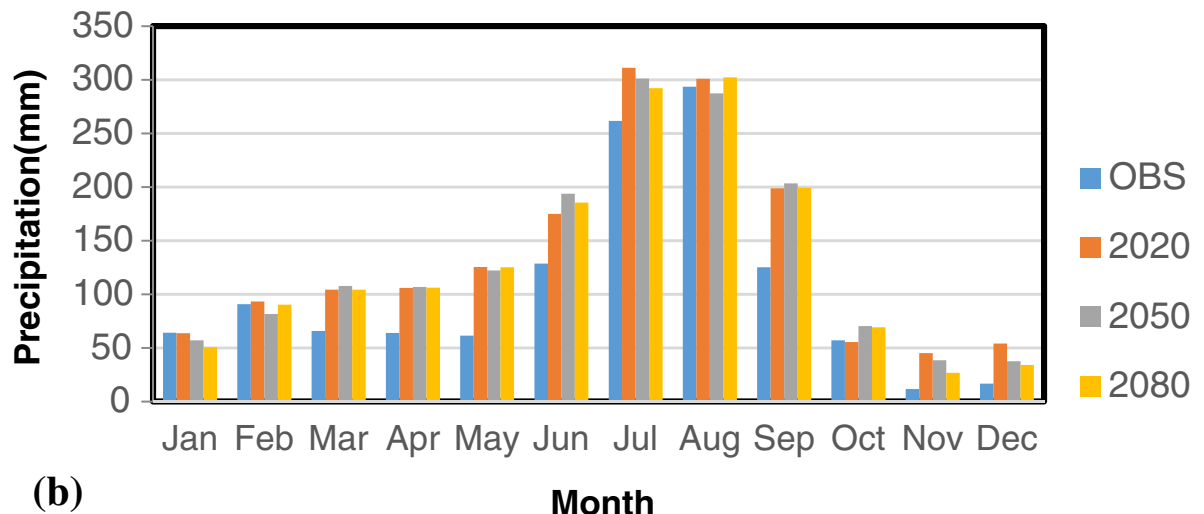

Figure 3. Change in average monthly precipitation (2001-2099) from base period (1960-1990) for (a) H3A2 and (b) H3B2 scenarios. 
during the monsoon season, particularly over the northwestern parts of India. Spatial patterns of rainfall change indicate a maximum increase over the west coast and northeast India for both A2 and B2 scenarios.

\subsection{Input factors of RUSLE model}

RUSLE model was used to estimate the potential annual soil loss in the watershed. The input factors were generated using remote sensing data and field survey. These factors were integrated in GIS for assessing potential soil erosion for each pixel. These RUSLE model factors are discussed below.

\subsubsection{Rainfall erosivity (R) factor}

Average annual rainfall erosivity was calculated for the current period (1985-2013), as well as for future period (2010-2099), under A2 and B2 scenarios. Thirty years average of annual rainfall erosivity for the current period, from 1985 to 2013, was estimated to be $546 \mathrm{~m}$ t ha- $\mathrm{cm}^{-1}$. Similarly, the average annual erosivity was calculated for three successive periods: 2011-2040, 2041-2070 and 2071-2099 for both scenarios (table 1). The rainfall erosivity value was estimated to be 701,686 and $657 \mathrm{~m} \mathrm{t}$ ha-cm ${ }^{-1}$, respectively, for A2 scenario and $693.8,684.2$ and $676.17 \mathrm{~m} \mathrm{t}$ ha- $\mathrm{cm}^{-1}$, respectively, for a B2 scenario. It was also found that rainfall erosivity may have an increasing trend up to $2020 \mathrm{~s}$, and after that, it may decline by 2.1 and $6.5 \%$ for 2050s and 2080s, respectively, under A2 scenario and 1.65 and $3.68 \%$ under B2 scenario. However, it is expected that it may vary in response to changes in climate due to change in erosive power of rainfall (Nearing 2001). It may increase due to increase in temperature, change in rainfall pattern (frequency and intensity) and land use/land cover (Beniston 2006; Trenberth 2011). According to Nearing (2001), the rainfall erosivity is changing significantly and might increase between 16 and $58 \%$ from the current (2000-2019) to future conditions (2080-2099). Plangoen and Babel (2014) studied the impact of climate change on rainfall erosivity and observed that it may increase up to $21 \%$ in the future. It is reported that there will be more intensification of the precipitation in the forthcoming decades and one of the most influencing factors will be the nature of the erosive power of rainfall (Nearing 2001; Pruski and Nearing 2002). Segura et al. (2014) evaluated the changes of $R$ from 1970 to 2090, across the United States, under nine climate conditions predicted by general circulation models (GCMs) for three emission scenarios (A2, A1B, and $\mathrm{B} 1)$.

\subsubsection{Soil erodibility $(K)$ factor}

Soil erodibility quantifies the cohesive character of a soil type, which depends upon the physicochemical properties of soil, thus contributing to its erodibility potential. The average percentage of sand, silt and clay were estimated to be 50.86 , 39.22 and $9.9 \%$, respectively, and the corresponding texture varied from silty loam to sandy loam. The soil erodibility in the watershed of the area ranged from 0.039 to $0.064 \mathrm{t} \mathrm{ha}^{-1} \mathrm{R}^{-1}$ (figure 4). The soil analysis revealed that the organic matter plays a vital role in reducing soil erodibilty. The average organic matter was found to be $5 \%$. The analysis from landscape units unveiled that soil erodibilty was higher in agricultural land, followed by scrubs and forest land. The average soil organic matter was found to be higher on low to moderate slopes $(5.3 \%)$ with good structure (fine granular), while lower in steep slopes (4\%) with coarse granular structure. $K$ values computed for each soil-landscape units are given in table 2 .

\subsubsection{Slope length (L) and steepness (S) factor}

Topographic factor represents the product of slope length $(L)$ and steepness $(S)$ factor. It describes the effect of topography on soil erosion and has a high value if the length and slope of terrain are more. The steep sloping area has high steepness factor (figure 5). The analysis revealed that $33.4 \%$ area of watershed had LS value $<10$ while $43.25,18.92$, $2.85,0.88$ and $0.66 \%$ area had the $L S$ value in the range of $10-25,25-50,50-75,75-100$ and $>100$, respectively (table 3 ). Higher $L S$ values of terrain represent higher susceptibility to soil erosion.

\subsubsection{Vegetation cover (C) factor}

Vegetation cover $(C)$ factor (figure 6 ) was computed using NDVI. NDVI provides better information

Table 1. Rainfall erosivity at various amount of precipitation of different scenarios.

\begin{tabular}{|c|c|c|c|c|c|c|}
\hline Scenario & \multicolumn{3}{|c|}{$\mathrm{A} 2$} & \multicolumn{3}{|c|}{$\mathrm{B} 2$} \\
\hline Average of 30 years & $\begin{array}{c}2020 \\
(2011-2040)\end{array}$ & $\begin{array}{c}2050 \\
(2041-2070)\end{array}$ & $\begin{array}{c}2080 \\
(2071-2099)\end{array}$ & $\begin{array}{c}2020 \\
(2011-2040)\end{array}$ & $\begin{array}{c}2050 \\
(2041-2070)\end{array}$ & $\begin{array}{c}2080 \\
(2071-2099)\end{array}$ \\
\hline Rainfall (mm) & 1652 & 1612 & 1534.66 & 1632 & 1607.2 & 1585.785 \\
\hline Rainfall erosivity ( $\mathrm{m} \mathrm{t}$ ha-cm ${ }^{-1}$ ) & 701 & 686 & 657 & 693.8 & 684.2 & 676.17 \\
\hline
\end{tabular}




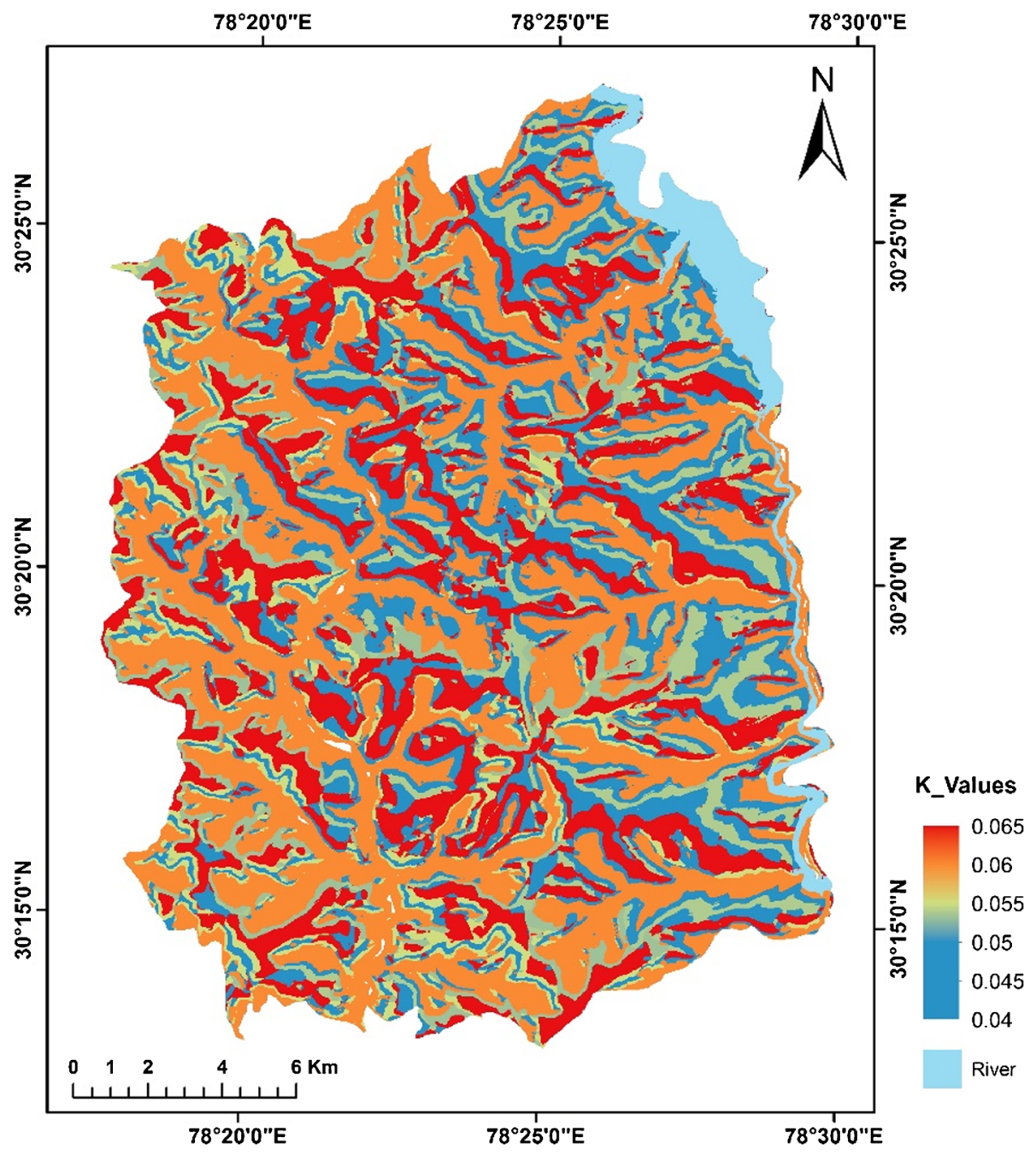

Figure 4. Soil erodibility $(K)$ factor.

Table 2. Soil erodibilty (K) factor values of various soil-landscape units.

\begin{tabular}{lccc}
\hline $\begin{array}{l}\text { Soil-landscape } \\
\text { units }\end{array}$ & $K$-value & $\begin{array}{c}\text { Soil-landscape } \\
\text { unit }\end{array}$ & $K$-value \\
\hline H1-A & 0.04 & H5-F & 0.06 \\
H1-F & 0.06 & H42-A & 0.04 \\
H41-A & 0.06 & H42-F & 0.05 \\
H31-F & 0.06 & H32-A & 0.06 \\
H31-A & 0.05 & H32-F & 0.05 \\
H21-A & 0.05 & H22-A & 0.06 \\
H21-F & 0.06 & H22-F & 0.05 \\
H5-A & 0.06 & & \\
\hline
\end{tabular}

- H1: Hill top, H2: Upper slope, H3: Middle slope, H4: Lower slope, H5: Valley.

- 1: North, 2: South.

- Agriculture, F: Forest, S: Scrub.

of vegetation cover condition and density (Hansen and Defries 2004; Heumann et al. 2007). It represented the spatial variability of $C$-factor in a better way. Many researchers (de Carvalho et al. 2012; Jinxing et al. 2014) have used NDVI to compute vegetation cover $(C)$ factor. The $C$-values range from 0 to 1 . The study area was mainly covered with forests $(34.87 \%)$, agriculture $(48.16 \%)$ and scrublands (17\%). The low values corresponded to dense forests whereas high values to the croplands and fallow lands. Table 4 illustrates the areal coverage for each $C$-factor class.

\subsubsection{Management practice $(P)$ factor}

The management practices followed in various $\mathrm{LU} / \mathrm{LC}$ were observed during the field survey and this information was used for assigning the $P$ values to each class (figure 7 ). Croplands in the area were terraced and the farmers maintained field bunds and risers in the terraced fields. Dense forest cover was largely under reserved forest category. A large area under forest was also classified under degraded forest and scrubland. These lands were found under higher erosion risk due to almost no management. $P$-values assigned to these land use/land cover classes are given in table 5 . 


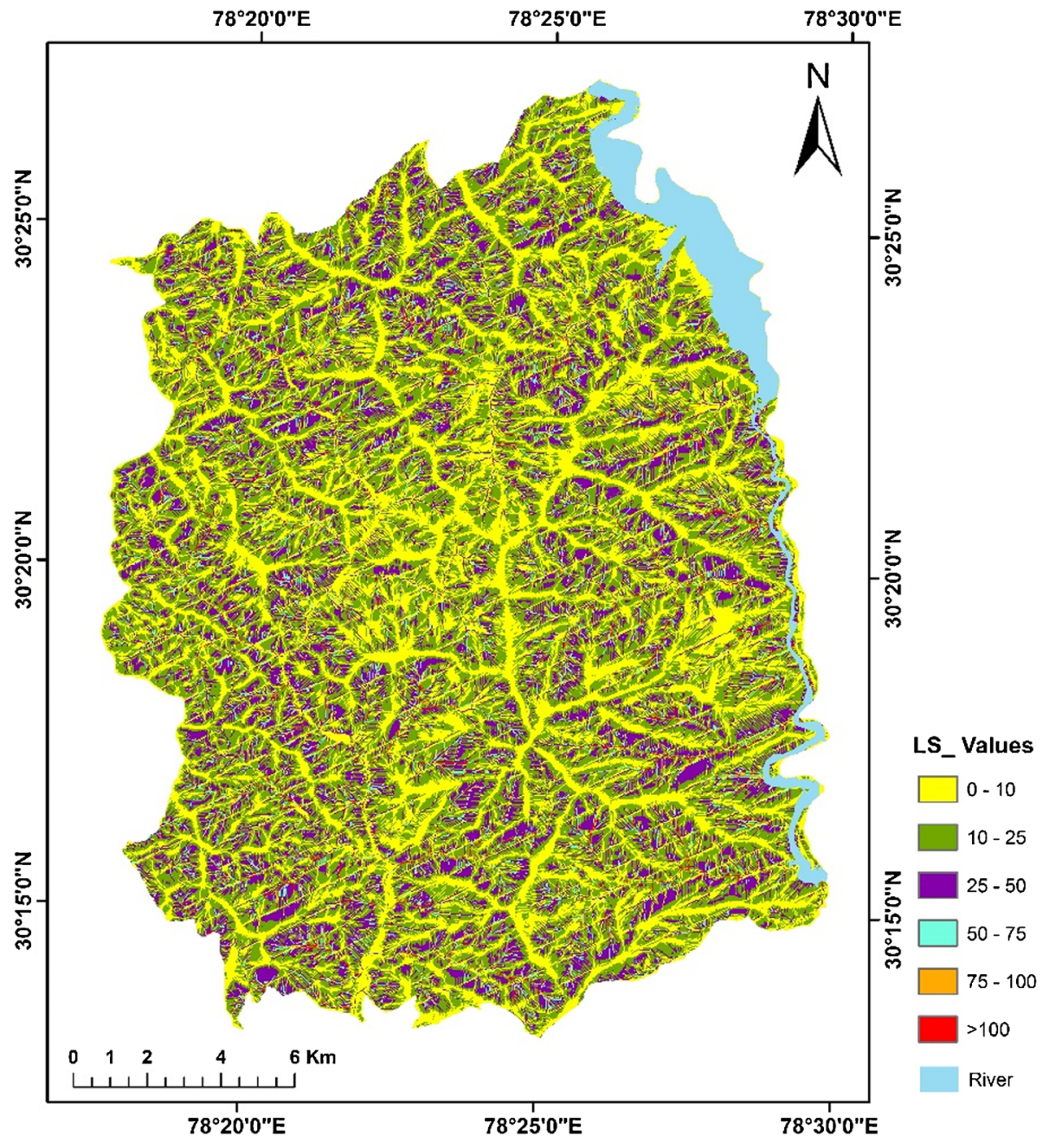

Figure 5. Slope length $(L)$ and steepness $(S)$ factor.

Table 3. LS factor values with area covered.

\begin{tabular}{lcr}
\hline LS classes & $\begin{array}{c}\text { Area } \\
\text { (ha) }\end{array}$ & $\begin{array}{c}\text { Area } \\
(\%)\end{array}$ \\
\hline $0-10$ & 12679.80 & 33.40 \\
$10-25$ & 16421.30 & 43.25 \\
$25-50$ & 7185.87 & 18.92 \\
$50-75$ & 1084.43 & 2.85 \\
$75-100$ & 336.81 & 0.88 \\
$>100$ & 252.99 & 0.66 \\
\hline
\end{tabular}

\subsubsection{Current soil erosion risk for base period (1985-2013)}

Potential annual soil loss was predicted by integrating $R, K, L S, C$ and $P$ factors in spatial analyst ArcGIS software. The analysis revealed that $21.49 \%$ area is affected by very low risk of erosion $\left(0-5 \mathrm{t} \mathrm{ha}^{-1} \mathrm{yr}^{-1}\right), 8.48 \%$ area with low risk $\left(5-10 \mathrm{t} \mathrm{ha}^{-1} \mathrm{yr}^{-1}\right), 15.54 \%$ area with moderate risk (10-20 t ha $\left.{ }^{-1} \mathrm{yr}^{-1}\right), 17.61 \%$ area with moderately high (20-40 $\left.\mathrm{t} \mathrm{ha}^{-1} \mathrm{yr}^{-1}\right), 16.12 \%$ area with high risk (40-80 $\mathrm{t} \mathrm{ha}^{-1} \mathrm{yr}^{-1}$ ) and $20.72 \%$ area with very high erosion $\left(>80 \mathrm{t} \mathrm{ha}^{-1} \mathrm{yr}^{-1}\right)$ risk (table 6$)$. The average soil loss was also computed for different land use/land cover. The analysis showed that the erosion was higher on barren lands (157 t ha $\mathrm{ha}^{-1}$ $\mathrm{yr}^{-1}$ ) and degraded forests (112.55 $\left.\mathrm{t} \mathrm{ha}^{-1} \mathrm{yr}^{-1}\right)$ followed by scrublands (55.45 $\left.\mathrm{t} \mathrm{ha}^{-1} \mathrm{yr}^{-1}\right)$ whereas, the erosion was lowest in the dense forests (15.67 $\mathrm{t} \mathrm{ha}^{-1} \mathrm{yr}^{-1}$ ) followed by moderate dense forest $\left(30.5 \mathrm{t} \mathrm{ha}^{-1} \mathrm{yr}^{-1}\right.$ ) (table 7 ). Dense forest (mixed tree) areas have a thick layer of their old leaf residue on the soil surface which is not removed and is continuously allowed to accumulate there. It provided protection cover on the land surface. Therefore, quite low erosion was observed in dense forest land. Agricultural and terraced fields were well maintained with stone patching and grasses. Therefore, moderate risk of erosion was observed in cropland (20.90 t ha $\mathrm{har}^{-1} \mathrm{yr}^{-1}$. The topographic factor $(L S)$ was found as the dominant factor for soil erosion as the erosion rate was predicted to be higher in steep to very steep slopes. The slope analysis with the erosion revealed that gentle and 


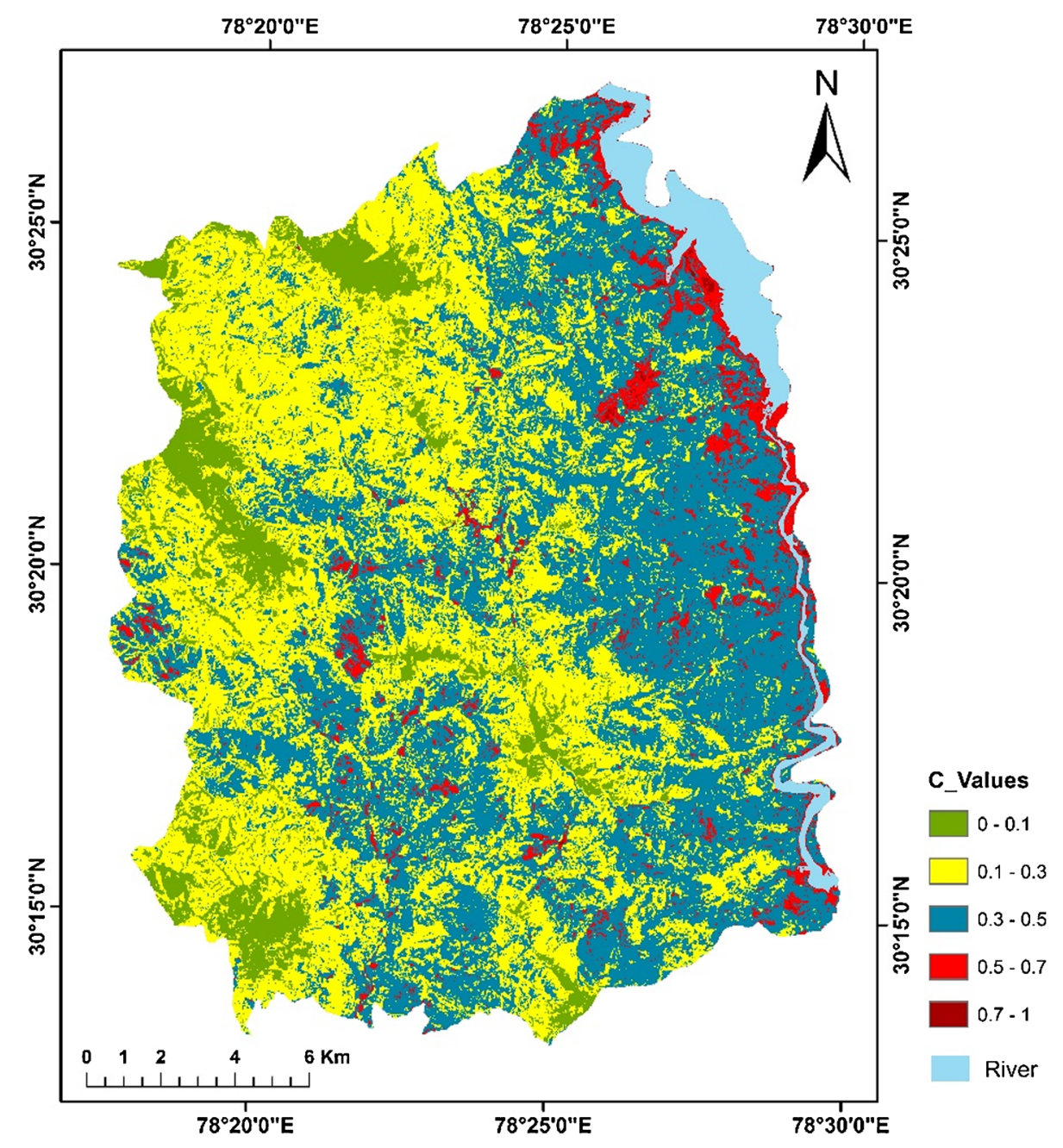

Figure 6. Crop cover $(C)$ factor.

Table 4. Crop cover factor $(C)$ values with area covered.

\begin{tabular}{lcr}
\hline Sl. no. & $C$-values & $\begin{array}{c}\text { Area } \\
(\%)\end{array}$ \\
\hline 1 & $0-0.1$ & 8.33 \\
2 & $0.1-0.3$ & 40.35 \\
3 & $0.3-0.5$ & 43.14 \\
4 & $0.5-0.7$ & 4.49 \\
5 & $0.7-1$ & 3.67 \\
\hline
\end{tabular}

moderate slopes were predicted to have lowest soil erosion rate of 8 and $33.5 \mathrm{tha}^{-1} \mathrm{yr}^{-1}$, respectively, whereas, highest soil erosion rate $\left(60 \mathrm{t} \mathrm{ha}^{-1} \mathrm{yr}^{-1}\right)$ was on the steep to very steep slopes. Aspect analysis showed the highest erosion in the southern aspect than the northern aspect of the hills. Similarly, higher rate of soil erosion was predicted on the steeper slopes, and it will be aggravated with the increasing rate of precipitation (Mondal et al. 2016). The soil erosion rate was predicted to increase by $58 \%$ in agriculture land and $59 \%$ in fallow land from the year of 2020s to 2080s.

\subsubsection{Validation of erosion assessment}

A total of 20 field sites were observed and characterised for soil erosion assessment during the field survey. $1 \times 1 \mathrm{~m}$ plots at these sites were observed. The past erosion features and soil erosion factors were characterised to assess soil erosion. The geographical coordinates of these sites were recorded using GPS. Soil loss of these sites was predicted using RUSLE model and these observed sites (points) were overlaid on the predicted soil erosion risk map to ascertain the accuracy of results. The model was validated with spatially distributed points characterised in the study area (table 8 ). Average soil erosion rate was computed using a $3 \times 3$ pixel window. The coefficient of determination $\left(r^{2}\right)$ and RMSE were computed to assess the accuracy of the model and were found to be $84.8 \%$ (figure 8 ) and $6.91 \mathrm{t} \mathrm{ha}^{-1} \mathrm{yr}^{-1}$, respectively. The RMSE was also studied for different land use/land cover and it was computed to 6.61, 5.13 and $8.21 \mathrm{t} \mathrm{ha}^{-1} \mathrm{yr}^{-1}$ in cropland, forest and scrubland category, respectively. The analysis thus 


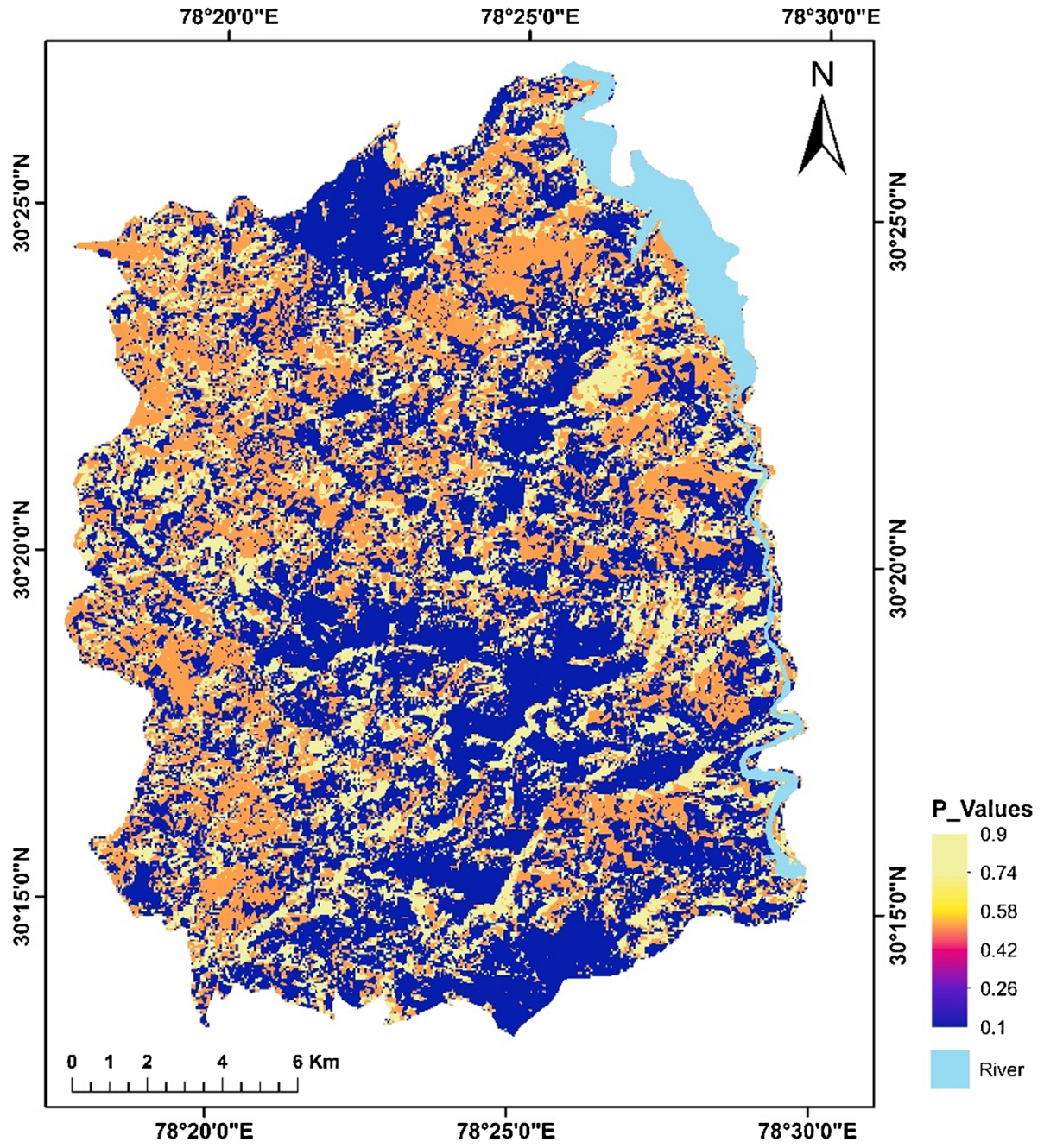

Figure 7. Crop management $(P)$ factor.

Table 5. P values assigned to various land use/land cover.

\begin{tabular}{llcrr}
\hline Sl. no. & $\quad$ LU/LC types & $\begin{array}{c}\text { Management } \\
\text { practice factor }\end{array}$ & $\begin{array}{c}\text { Area } \\
(\text { ha })\end{array}$ & $\begin{array}{c}\text { Area } \\
(\%)\end{array}$ \\
\hline 1 & Dense forest & 0.1 & 2415.45 & 6.54 \\
2 & Moderate dense forest & 0.8 & 8789.25 & 23.81 \\
3 & Deg. forest & 0.9 & 8223.13 & 22.28 \\
4 & Scrubland & 0.8 & 8559.12 & 23.19 \\
5 & Cropland & 0.2 & 8369.87 & 22.67 \\
6 & Waste land & 0.9 & 69.78 & 0.19 \\
7 & Built up & 0.9 & 119.95 & 0.32 \\
8 & Water bodies & 0 & 365.92 & 0.99 \\
\hline
\end{tabular}

revealed that the soil erosion was predicted quite well with RUSLE model.

\subsubsection{Soil erosion risk scenario in future}

Soil erosion was predicted with respect to the change in rainfall erosivity (climate factor), while the other factors were kept constant. The RUSLE model was run to estimate soil erosion for future climate scenarios. The mean of 30 years of future
Table 6. Area under various soil erosion risk classes in the watershed.

\begin{tabular}{lccc}
\hline $\begin{array}{l}\text { Soil erosion } \\
\text { classes }\end{array}$ & $\begin{array}{c}\text { Rate of soil loss } \\
\left(\mathrm{t} \mathrm{ha}^{-1} \mathrm{yr}^{-1}\right)\end{array}$ & $\begin{array}{c}\text { Area } \\
(\text { ha })\end{array}$ & $\begin{array}{c}\text { Area } \\
(\%)\end{array}$ \\
\hline Very low & $0-5$ & 7888.82 & 21.49 \\
Low & $5-10$ & 3112.64 & 8.48 \\
Moderate & $10-20$ & 5705.48 & 15.54 \\
Moderately high & $20-40$ & 6464.99 & 17.61 \\
High & $40-80$ & 5916.49 & 16.12 \\
Very high & $>80$ & 7604.43 & 20.72 \\
\hline
\end{tabular}

Table 7. Average soil loss ( $\left.t h a^{-1} y r^{-1}\right)$ in various land use/ land cover types.

\begin{tabular}{llrr}
\hline Sl. no. & \multicolumn{1}{c}{ Classes } & $\begin{array}{c}\text { Avg. soil loss } \\
\left(\mathrm{t} \mathrm{ha}^{-1} \mathrm{yr}^{-1}\right)\end{array}$ & \multicolumn{1}{c}{$\begin{array}{c}\text { Area } \\
(\%)\end{array}$} \\
\hline 1 & Dense forest & 15.67 & 6.54 \\
2 & Moderate dense forest & 30.50 & 23.81 \\
3 & Deg. forest & 112.50 & 22.28 \\
4 & Cropland & 20.90 & 22.67 \\
5 & Scrubland & 55.45 & 23.19 \\
6 & Waste land/ROC & 157.75 & 0.19 \\
\hline
\end{tabular}


Table 8. Comparison between Observed $\&$ Predicted soil loss at the 20 field sites.

\begin{tabular}{|c|c|c|c|c|c|c|c|c|c|}
\hline Sites & Latitude & Longitude & 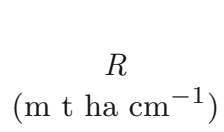 & $\begin{array}{c}K \\
\left(\mathrm{t} \mathrm{ha}^{-1} / \mathrm{R}\right)\end{array}$ & $L S$ & $C$ & $P$ & $\begin{array}{c}\text { Soil loss } \\
\text { (observed) } \\
\text { t ha }{ }^{-1} \mathrm{yr}^{-1}\end{array}$ & $\begin{array}{c}\text { Soil loss } \\
\text { (predicted) } \\
\mathrm{t} \mathrm{ha}^{-1} \mathrm{yr}^{-1}\end{array}$ \\
\hline 1 & 30.399611 & 78.4385 & 546.00 & 0.07 & 28.79 & 0.20 & 0.20 & 43.40 & 47.54 \\
\hline 2 & 30.373333 & 78.390333 & 546.00 & 0.08 & 13.05 & 0.20 & 0.20 & 22.06 & 24.72 \\
\hline 3 & 30.377056 & 78.395333 & 546.00 & 0.07 & 18.95 & 0.20 & 0.10 & 30.04 & 17.78 \\
\hline 4 & 30.235694 & 78.353972 & 546.00 & 0.05 & 26.05 & 0.20 & 0.20 & 27.49 & 33.87 \\
\hline 5 & 30.300972 & 78.423611 & 546.00 & 0.05 & 3.98 & 0.04 & 0.80 & 3.34 & 2.40 \\
\hline 6 & 30.301611 & 78.402722 & 546.00 & 0.08 & 32.84 & 0.04 & 0.20 & 46.94 & 47.01 \\
\hline 7 & 30.291361 & 78.399889 & 546.00 & 0.06 & 22.32 & 0.20 & 0.20 & 31.23 & 36.62 \\
\hline 8 & 30.413944 & 78.342333 & 546.00 & 0.05 & 1.24 & 0.01 & 0.10 & 0.02 & 0.69 \\
\hline 9 & 30.417889 & 78.339 & 546.00 & 0.03 & 6.56 & 0.01 & 0.10 & 0.07 & 6.09 \\
\hline 10 & 30.418333 & 78.339139 & 546.00 & 0.10 & 3.49 & 0.01 & 0.10 & 0.11 & 2.22 \\
\hline 11 & 30.399028 & 78.364278 & 546.00 & 0.07 & 22.42 & 0.01 & 0.10 & 0.54 & 8.56 \\
\hline 12 & 30.294167 & 78.419972 & 546.00 & 0.04 & 2.47 & 0.20 & 0.80 & 2.16 & 2.97 \\
\hline 13 & 30.293694 & 78.423861 & 546.00 & 0.04 & 3.84 & 0.20 & 0.20 & 3.66 & 4.03 \\
\hline 14 & 30.317556 & 78.405611 & 546.00 & 0.03 & 8.18 & 0.20 & 0.80 & 5.58 & 13.14 \\
\hline 15 & 30.317222 & 78.406278 & 546.00 & 0.05 & 5.47 & 0.04 & 0.20 & 4.39 & 13.22 \\
\hline 16 & 30.320639 & 78.401389 & 546.00 & 0.04 & 21.53 & 0.20 & 0.20 & 21.07 & 32.73 \\
\hline 17 & 30.391086 & 78.40362 & 546.00 & 0.07 & 3.71 & 0.08 & 0.80 & 8.62 & 5.14 \\
\hline 18 & 30.404519 & 78.431809 & 546.00 & 0.07 & 14.61 & 0.08 & 0.80 & 33.97 & 46.07 \\
\hline 19 & 30.365525 & 78.403516 & 546.00 & 0.07 & 9.63 & 0.08 & 0.80 & 21.99 & 14.39 \\
\hline 20 & 30.389207 & 78.424433 & 546.00 & 0.06 & 22.27 & 0.08 & 0.80 & 50.04 & 39.14 \\
\hline
\end{tabular}

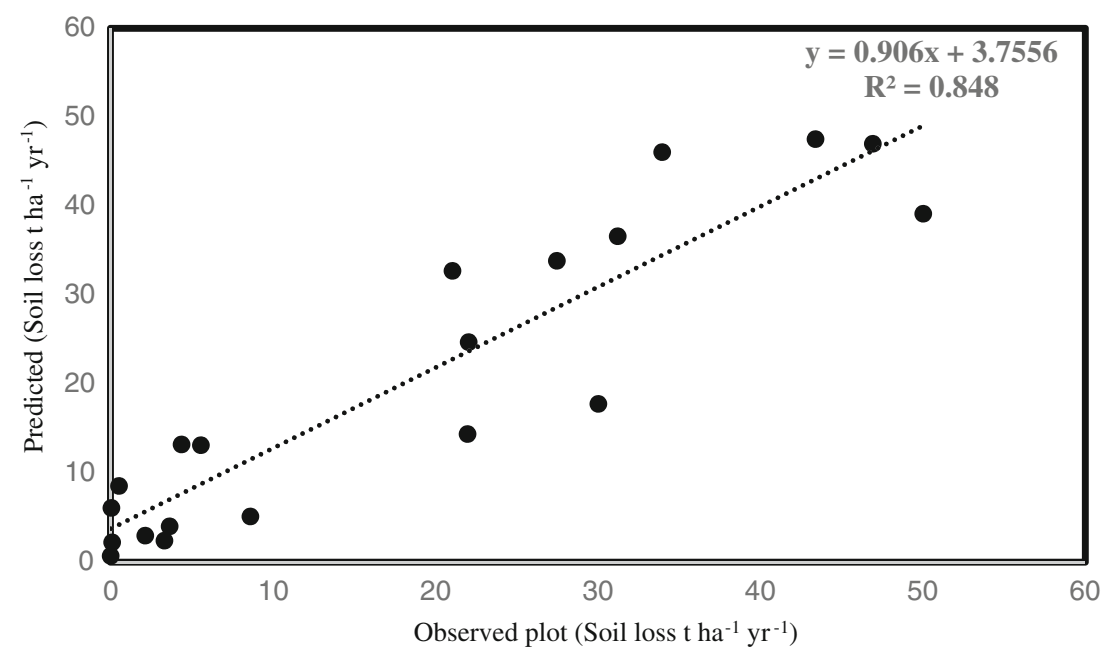

Figure 8. Scatterplot between predicted and observed soil loss $\left(\mathrm{t} \mathrm{ha}^{-1} \mathrm{yr}^{-1}\right)$.

precipitation during the period of 2011-2099 was taken in three periods denoted as 2020s, 2050s and 2080s. The 2020s represents the mean of 2011-2040, 2050s represents the mean of 20412070, and 2080s represents the time from 2071 to 2099. The results unveiled that the average annual soil loss may increase by $28.38,25.64$ and $20.33 \%$ in year 2020s, 2050s and 2080s, respectively under A2 scenario (figure 9b, c, d and table 9). Likewise, average annual soil loss may increase by $27.06,25.31$ and $23.38 \%$ in 2020 s, 2050s and 2080s under B2 scenario (figure 9e, f, g and table 10) from the base period (1985-2013) (figure 9a). The average soil erosion rate in cropland will be increased from 20.90 (base period) to $26.90 \mathrm{t} \mathrm{ha}^{-1} \mathrm{yr}^{-1}(2020 \mathrm{~s}), 26.30(2050 \mathrm{~s})$ and $25.20(2080 \mathrm{~s})$ and $26.6090(2020 \mathrm{~s}), 26.23(2050 \mathrm{~s})$ and $25.92 \mathrm{t} \mathrm{ha}^{-1} \mathrm{yr}^{-1}$ (2080s) under A2 and B2 scenarios, respectively. The average soil erosion rate in dense forest, degraded and barren lands will be increased from 15.67 (base period) to 20.15 (2020s), 19.70 (2050s) and 18.88 (2080s); 112.50 (base period) to $144(2020 \mathrm{~s}), 141.63(2050 \mathrm{~s})$ and 135.71 (2080s); 157.75 (base period) to 202.00 

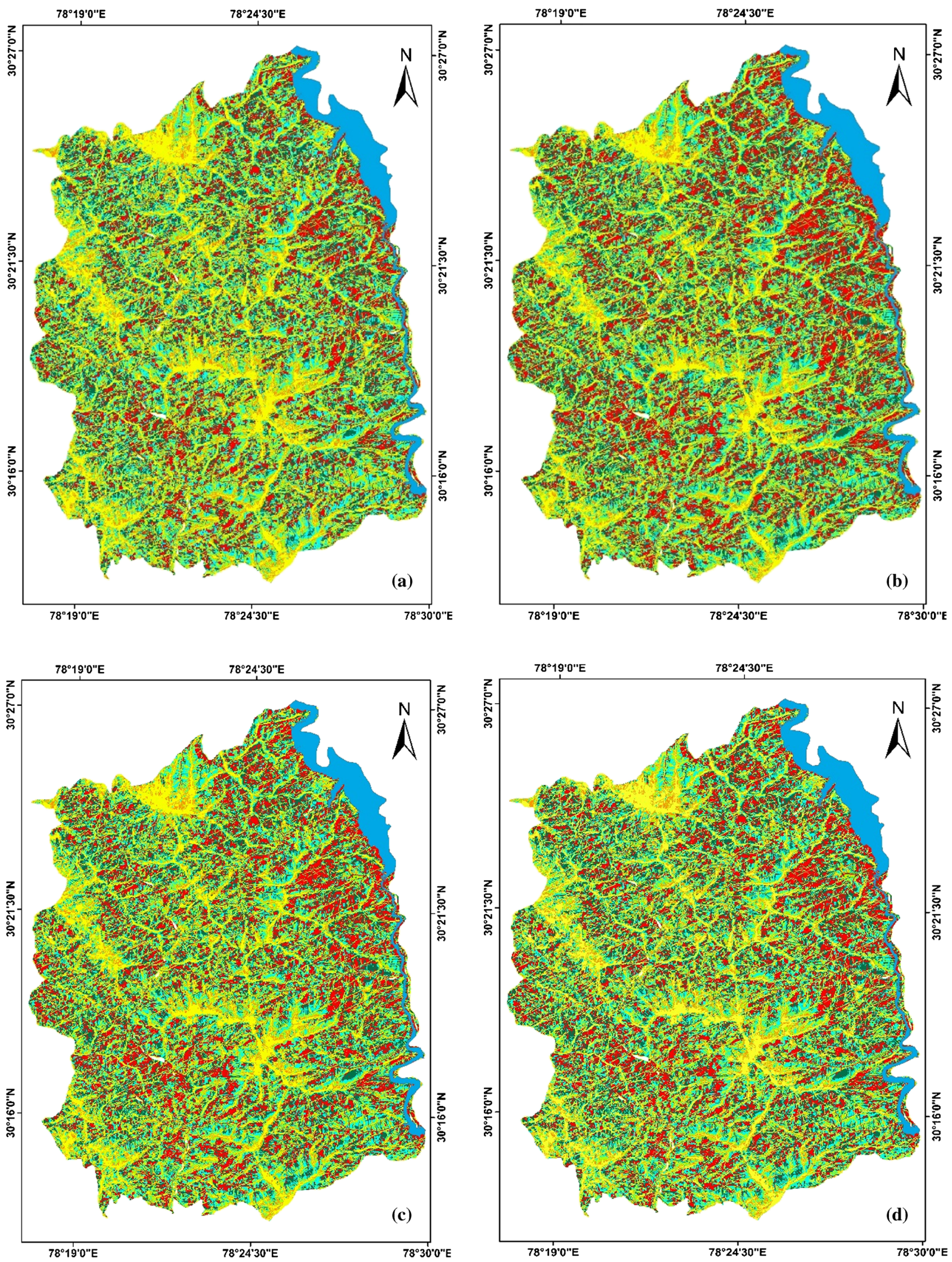

Figure 9. Soil erosion scenario under (b, c, d) A2 and (e, f, g) B2 scenario for 2020, 2050 and 2080 period from base period $(\mathbf{a})$. 

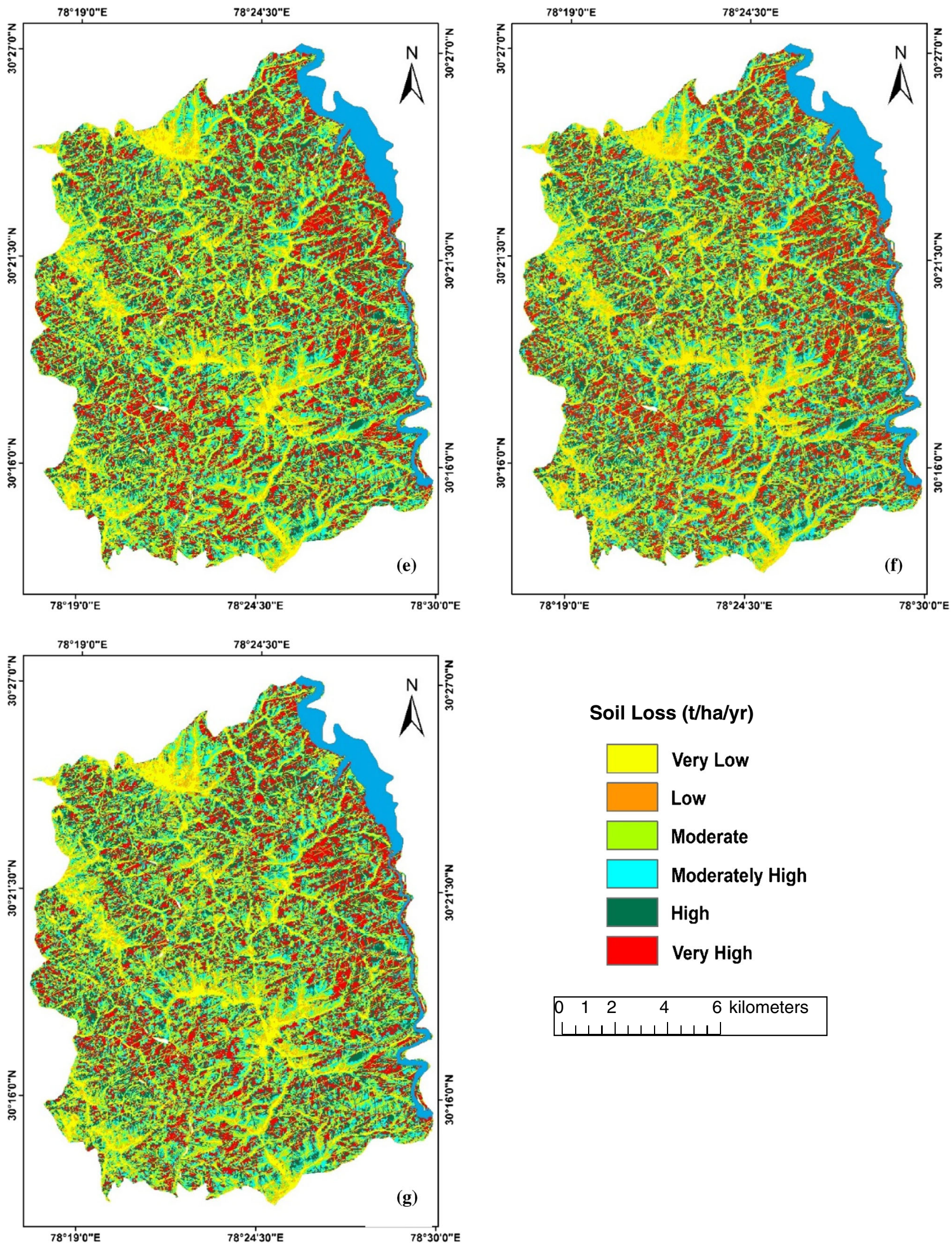

Soil Loss (t/ha/yr)
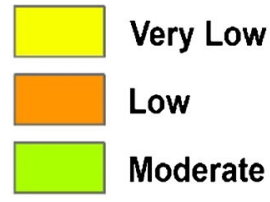

Moderately High

High

Very High

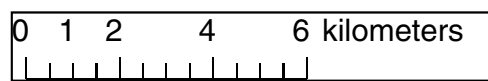

Figure 9. (Continued.) 
Table 9. Average annual soil loss $\left(t h a^{-1} \mathrm{yr}^{-1}\right)$ in various land use/land cover for current and future period under A2 scenario.

\begin{tabular}{lrrrrrr}
\hline Classes & & & & Base year & $\begin{array}{c}\text { Base year } \\
\text { Base year } \\
\text { to 2050 }(\%)\end{array}$ \\
to 2080 (\%)
\end{tabular}

Table 10. Average annual soil loss $\left(t h a^{-1} y r^{-1}\right)$ in various land use/land cover for current and future period under B2 scenario.

\begin{tabular}{|c|c|c|c|c|c|c|c|}
\hline Classes & Present & 2020 & 2050 & 2080 & $\begin{array}{c}\text { Base year } \\
\text { to } 2020(\%)\end{array}$ & $\begin{array}{c}\text { Base year } \\
\text { to } 2050(\%)\end{array}$ & $\begin{array}{c}\text { Base year } \\
\text { to } 2080(\%)\end{array}$ \\
\hline Dense forest & 15.67 & 19.93 & 19.65 & 19.42 & 27.19 & 25.41 & 23.94 \\
\hline Moderate dense forest & 30.50 & 38.74 & 38.21 & 37.77 & 27.00 & 25.28 & 23.84 \\
\hline Deg. forest & 112.50 & 143.24 & 141.26 & 139.60 & 27.32 & 25.56 & 24.09 \\
\hline Scrubland & 55.45 & 70.42 & 69.47 & 68.66 & 27.00 & 25.28 & 23.82 \\
\hline Cropland & 20.90 & 26.60 & 26.23 & 25.92 & 27.27 & 25.50 & 24.02 \\
\hline Wasteland & 157.75 & 199.78 & 197.02 & 194.71 & 26.65 & 24.90 & 23.43 \\
\hline
\end{tabular}

(2020s), 197.54 (2050s) and $189.29 \mathrm{t} \mathrm{ha}^{-1} \mathrm{yr}^{-1}$ (2080s) under A2 scenario whereas average soil erosion rate in dense forest, degraded and barren lands will be increased from 15.67 (base period) to $19.93(2020 \mathrm{~s}), 19.65$ (2050s) and 19.42 (2080s); 112.50 (base period) to 143.24 (2020s), $141.26(2050 \mathrm{~s})$ and 139.60 (2080s); 157.75 (base period) to 199.78 (2020s), $197.02(2050 \mathrm{~s})$ and $194.71 \mathrm{t} \mathrm{ha}^{-1} \mathrm{yr}^{-1}(2080 \mathrm{~s})$ under B2 scenario. The study revealed the highest soil erosion rate in barren lands (157.75-202.70 $\left.\mathrm{t} \mathrm{ha} \mathrm{har}^{-1}\right)$ followed by degraded forests $\left(112.5-144.0 \mathrm{t} \mathrm{ha}^{-1}\right.$ $\mathrm{yr}^{-1}$ ) and scrublands (55.45-70.42 $\left.\mathrm{t} \mathrm{ha}^{-1} \mathrm{yr}^{-1}\right)$. However, dense forest was found to have lowest soil erosion risk (15.67-20.15 t ha $\left.\mathrm{hr}^{-1}\right)$. Cropland was observed to have moderate erosion rate (20.90-26.90 $\left.\mathrm{t} \mathrm{ha}^{-1} \mathrm{yr}^{-1}\right)$ from year of base period to future scenario.

Climate change effect on soil erosion showed changes in the erosion rate due to changed rainfall behaviour (Routschek et al. 2014a, b). Nearing (2001) showed critical changes in rainfall erosivity of up to $58 \%$ in USA, which may considerably affect future soil erosion rates. Expected increased intensity of precipitation will lead to increased loss of soil which was also observed in various other studies (Zhang et al. 2010; Wurbs and Steininger 2011). Mondal et al. (2016) showed an increasing trend of future precipitation and a probable increase in rate soil erosion in all stations of Madhya Pradesh, India. Zhang et al. (2012) predicted average soil loss may increase by $44 \%$ using GCM data in central Oklahoma. Yang et al. (2003) estimated a global average increase in soil loss of 14\% under climate change using a GIS-based RUSLE model. The spatial distribution of land use/land cover has been assumed to remain constant over time even though it is understood that it may likely to change in the future. Rainfall erosivity $(R)$ was computed using empirical relation based on monthly rainfall data. These empirical methods are crude because they fail to fully reflect possible $R$ changes due to the increases in large extreme rainfall events, which is one of the most significant aspects of future climate change (Segura et al. 2014).

\section{Conclusion}

Statistical downscaling model (SDSM) was used to downscale the climatic variable (precipitation) from coarse resolution GCM data to fine resolution at a point scale. The point scale represents the local weather as the model was calibrated and validated with the data obtained from the weather station located in the watershed. Downscaling was better in a case of precipitation, which was evident from the coefficient of determination $\left(r^{2}=0.71-0.80\right)$. The study revealed that the precipitation may increase till 2020 and then it may reduce in 2050 and 2080 as compared to 2020. RUSLE model was used for predicting the annual soil loss in the watershed for the current year. Downscaled precipitation data for future periods were used to calculate the average rainfall erosivity for the year of 2020s, 2050s and 2080s. Rainfall erosivity may 
increase from 546 to $701 \mathrm{~m} \mathrm{t}$ ha- $\mathrm{cm}^{-1}$ under the A2 scenario, whereas 546 to $693.8 \mathrm{~m} \mathrm{t}$ ha- $\mathrm{cm}^{-1}$ under B2 scenario.

RUSLE model estimated $39.97 \%$ of area under very low to low risk of erosion $\left(0-10 \mathrm{t} \mathrm{ha}^{-1} \mathrm{yr}^{-1}\right)$, $33.15 \%$ area with moderate to moderately high erosion risk (10-40 $\left.\mathrm{t} \mathrm{ha}^{-1} \mathrm{yr}^{-1}\right)$ and $36.84 \%$ area with high erosion (40-80 $\left.\mathrm{t} \mathrm{ha}^{-1} \mathrm{yr}^{-1}\right)$ to very high risk of erosion $\left(>80 \mathrm{t} \mathrm{ha}^{-1} \mathrm{yr}^{-1}\right)$ in the current year. The study showed highest soil erosion rate in barren lands (rock out crop) (157 $\left.\mathrm{t} \mathrm{ha}^{-1} \mathrm{yr}^{-1}\right)$ and degraded forests $\left(112.55 \mathrm{t} \mathrm{ha}^{-1} \mathrm{yr}^{-1}\right)$ followed by scrublands ( $55.45 \mathrm{t} \mathrm{ha}^{-1} \mathrm{yr}^{-1}$ ), whereas the erosion rate was lowest in the dense $\left(15.67 \mathrm{t} \mathrm{ha}^{-1} \mathrm{yr}^{-1}\right)$ and moderately dense $\left(30.5 \mathrm{t} \mathrm{ha}^{-1} \mathrm{yr}^{-1}\right)$ forests. Cropland area was predicted with an average soil loss of $20.90 \mathrm{t} \mathrm{ha}^{-1} \mathrm{yr}^{-1}$. Further, the soil erosion was predicted for future periods and the results unveiled that the average annual soil loss may increase by $28.38,25.64$ and $20.33 \%$ in 2020 s, 2050 s and 2080 s, respectively under the A2 scenario. Similarly, average annual soil loss may increase by 27.06 , 25.31 and $23.38 \%$ in 2020s, 2050s and 2080s, respectively under B2 scenario from the base period (1985-2013).

The study has a limitation as it has considered only climatic factor (rainfall erosivity) as a change in future keeping other factors constant in future climatic scenarios. The accuracy of rainfall erosivity $(R)$ is also limited to both the accuracy of the precipitation projections and the effectiveness of the empirical relationship employed for its computation. Precipitation projections by different GCM models and emission scenarios provide varying projections of future climate. In the methodology, $R$ was computed based on an empirical equation using monthly precipitation data. However, available GCMs do not offer precipitation data resolved at a higher temporal scale. The land use/land cover has been considered as constant, which is expected may change in future. The present study had been carried out using most widely used GCM data of both scenarios (A2 and B2) and downscaling at fine scale by calibrating and validation with weather station data with good agreement. It is to note that the study does not provide precise estimates but provides a comprehensive understanding of the possible future scenario of soil erosion in the mid-Himalaya for scientists and policy makers.

\section{Acknowledgements}

Authors are sincerely thankful to Indian Space Research Organisation (ISRO) for providing financial support under Earth Observation Applications Mission (EOAM) project (ISRO/DOS) on 'Mountain Ecosystem Processes and Services' to carry out the research work. We are grateful to Department of Meteorology, Uttarakhand University of Horticulture and Forestry for Ranichauri (Uttarakhand) for providing weather data for used for validation. We sincerely thank Dr S K Saha, Ex-Dean (A) and Director, IIRS for encouraging the present research work.

\section{References}

Adediji A, Tukur A M and Adepoju K A 2010 Assessment of revised universal soil loss equation (RUSLE) in Katsina area, Katsina state of Nigeria using remote sensing (RS) and geographic information system (GIS) Iranica; J. Energy Environ. 1(3) 255-264.

Arnoldous H M J 1978 An approximation of the rainfall factor in the USLE in assessment of erosion; Wiley, Chichester, England.

Beniston M 2006 Mountain weather and climate: A general overview and a focus on climatic change in the Alps; Hydrobiologia 562 3-16.

Boardman J and Favis-Mortlock D T 1993 Climate change and soil erosion in Britain; Geogr. J. 159(2) 179-183.

Collins M, Tett S F B and Cooper C 2001 The internal climate variability of HadCM3, a version of the Handley Center coupled model without flux adjustments; Clim. Dyn. 17(1) 61-81.

Daba M, Mamo G and Rao G N 2013 Evaluating potential impact of climate change on hydro-meteorological variables in upper blue Nile Basin. A case study Fincha subbasin; Impacts World 2013, International Conference on Climate Change Effects, Potsdam, May 27-30.

de Carvalho D F, Khouryjúnior J K, Varella C A A, Giori J Z and Machado R L 2012 Rainfall erosivity for the state of Rio de Janeiro estimated by artificial neural network; Eng. Agríc. 32 197-207.

De Jong S M, Paracchini M L, Bertolo F, Folving S, Megier J and De Roo A PJ 1999 Regional assessment of soil erosion using the distributed model SEMMED and remotely sensed data; Catena 37(3-4) 291-308.

Durigon V L, Carvalho D F, Antunes M A H, Oliveira P T S and Fernandes M M 2014 NDVI time series for monitoring RUSLE cover management factor in a tropical watershed; Int. J. Remote Sens. 35 441-453.

Flato G et al. 2013 Evaluation of climate models; In: Climate Change 2013: The Physical Science Basis, Contribution of Working Group I to the Fifth Assessment Report of the Intergovernmental Panel on Climate Change (eds) Stocker T F, Qin D, Plattner G K, Tignor M, Allen S K, Boschung J, Nauels A, Xia Y, Bex V, and Midgley P M, Cambridge University Press, Cambridge, United Kingdom and New York, NY, USA.

Gagnon S, Singh B, Rousselle J and Roy L 2005 An application of the statistical downscaling model (SDSM) to simulate climatic data for stream flow modelling in Québec; Can. Water Resour. J. 30(4) 297-314.

Hansen M C and Defries R S 2004 Detecting long-term global forest change using continuous fields of tree-cover maps from 8-km Advanced Very High Resolution Radiometer (AVHRR) data for the years 1982-1999; Ecosystems 7 695-716.

Hansen J W and Indeje M 2004 Linking dynamic seasonal climate forecasts with crop simulation for maize yield prediction in semi-arid Kenya; Agr. Forest Meteorol. 125(1-2) 143-157. 
Hassan Z, Shamsudin S and Harun S 2014 Application of SDSM and LARS-WG for simulating and downscaling of rainfall and temperature; Theor. Appl. Climatol. 116 (1-2) 243-257.

Heumann B W, Seaquist J W, Eklundh L and Jönsson P 2007 AVHRR derived phenological change in the Sahel and Soudan, Africa 1982-2005; Remote Sens. Environ. $108385-392$.

Houghton J T, Ding Y D J G, Griggs D J, Noguer M, van der Linden P J, Dai X, Maskell K and Johnson C A 2001 Climate Change 2001: The scientific basis; Cambridge University Press, Cambridge, UK.

IPCC (Intergovernmental Panel on Climate Change) 2001 Climate Change 2001: The scientific basis; Contribution of Working Group I to the Third Assessment Report of the IPCC; Cambridge University Press, Cambridge, UK.

Jain S K and Goel M K 2002 Assessing the vulnerability to soil erosion of the Ukai Dam catchments using remote sensing and GIS; Hydrol. Sci. J. 47(1) 31-40.

Jenny H 1941 Factors of soil formation: A system of quantitative pedology; McGraw-Hill, New York.

Jiang Z, Su S, Jing C, Lin S, Fei X and Wu J 2012 Spatiotemporal dynamics of soil erosion risk for Anji County, China; Stoch. Env. Res. Risk A 26(6) 751-763.

Jinxing C, Depeng Y, Shu S and Mengchao M 2014 Design and implementation of soil loss system based on RUSLE; WSEAS Trans. Infor. Sci. Appl. 11 204-213.

Joshi, R, Kumar, K and Palni, L M S (eds) 2015 Dynamics of climate change and water resources of northwestern Himalaya, Springer.

Kannan S and Ghosh S 2011 Prediction of daily rainfall state in a river basin using statistical downscaling from GCM output; Stoch. Environ. Res. Risk. Assess. 25(4) 457-474.

Knutti R, Masson D and Gettelman A 2013 Climate model genealogy: Generation CMIP5 and how we got there; Geophys. Res. Lett. 40 1194-1199.

Kouli M, Soupios P and Vallianatos F 2009 Soil erosion prediction using the Revised Universal Soil Loss Equation (RUSLE) in a GIS framework, Chania, northwestern Crete, Greece; Environ. Geol. 57 483-497.

Kumar S and Khushwaha S P S 2013 Modeling soil erosion risk based on RUSLE-3D using GIS in a Shivalik subwatershed; J. Earth Syst. Sci. 122(2) 389-398.

Kumar K R, Sahai A K, Kumar K K, Patwardhan S K, Mishra P K, Revadekar J V, Kamala K and Pant G B 2006 High-resolution climate change scenarios for India for the 21st century; Curr. Sci. 90(3) 334.

Lal R 1998 Soil erosion impact on agronomic productivity and environment quality; Crit. Rev. Plant Sci. 17(4) 319-464.

Lal R 2005 Soil erosion and carbon dynamics; Soil Tillage Res. 81 137-142.

Li Z, Liu W Z, Zhang X C and Zheng F L 2011 Assessing the site-specific impacts of climate change on hydrology, soil erosion and crop yields in the Loess Plateau of China; Climatic Change 105(1-2) 223-242.

Lin C Y, Lin W T and Chou W C 2002 Soil erosion prediction and sediment yield estimation: The Taiwan experience; Soil Till. Res. 68(2) 143-152.

Lin W T, Lin C Y and Chou W C 2006 Assessment of vegetation recovery and soil erosion at landslides caused by a catastrophic earthquake: A case study in central Taiwan; Ecol. Eng. 28(1) 79-89.

Lu D, Li G, Valladares G S and Batistella M 2004 Mapping soil erosion risk in Rondonia, Brazilian Amazonia using RUSLE, remote sensing and GIS; Land Degrad. Dev. 15(4) 499-512.

Mahmood R and Babel M S 2012 Evaluation of SDSM developed by annual and monthly sub-models for downscaling temperature and precipitation in the Jhelum basin, Pakistan and India; Theor. Appl. Climatol. 11 (1-2) 27-44.

Meenu R, Rehana S and Mujumdar P P 2012 Assessment of hydrologic impacts of climate change in Tunga-Bhadra river basin, India, with HEC-HMS and SDSM; Hydrol. Process. 27(11) 1572-1589.

Michael A, Schmidt J, Enke W, Deutschlander T and Maltiz G 2005 Impact of expected increase in precipitation intensities on soil loss results of comparative model simulations; Catena 61 155-164.

Millward A A and Mersey J E 1999 Adapting the RUSLE to model soil erosion potential in a mountainous tropical watershed; Catena 38(2) 109-129.

Mitasova H, Hofierka J, Zlocha M and Iverson R 1996 Modeling topographic potential for erosion and deposition using GIS; Int. J. Geogr. Inf. Syst. 10(5) 629-641.

Mondal A, Khare D and Kundu S 2016 Impact assessment of climate change on future soil erosion and SOC loss; Nat. Hazards 82 1515-1539.

Moore I D and Wilson J P 1992 Length-slope factors for revised universal soil loss equation: Simplified method of estimation; J. Soil Water Conserv. 47(5) 423-428.

Neal M R, Nearing M A, Vining R C, Southworth J and Pfeifer R A 2005 Climate change impacts on soil erosion in midwest United States with changes in crop management; Catena 61 165-184.

Nearing M A 2001 Potential changes in rainfall erosivity in the US with climate change during the 21st century; J. Soil Water Conserv. 56(3) 229-232.

Nearing M A, Pruski F F and O'neal M R 2004 Expected climate change impacts on soil erosion rates: A review; J. Soil Water Conserv. 59(1) 43-50.

Nelson D W and Sommers L E 1996 Total carbon, organic carbon, and organic matter; In: Methods of Soil Analysis, Part 2 (eds) Page A L et al., Agronomy, Am. Soc. Agron., Inc. Madison, WI 9 961-1010.

Pimentel D 2006 Soil erosion: A food and environmental threat; Environ. Dev. Sustain. 8(1) 119-137.

Plangoen P and Babel M S 2014 Projected rainfall erosivity changes under future climate in the Upper Nan Watershed, Thailand; J. Earth Sci. Clim. Change 5(10) 1.

Plangoen P, Babel M S, Clemente R S, Shrestha S and Tripathi N K 2013 Simulating the impact of future land use and climate change on soil erosion and deposition in the Mae Nam Nan sub-catchment, Thailand; Sustainability 5(8) 3244-3274.

Prasannakumar V, Shiny R, Geetha N and Vijith H 2011 Spatial prediction of soil erosion risk by remote sensing, GIS and RUSLE approach: A case study of Siruvani river watershed in Attapady valley, Kerala, India; Environ. Earth Sci. 64(4) 965-972.

Prasannakumar V, Vijith H, Abinod S and Geetha N 2012 Estimation of soil erosion risk within a small mountainous sub-watershed in Kerala, India, using Revised Universal Soil Loss Equation (RUSLE) and geo-information technology; Geosci. Frontiers 3(2) 209-215.

Priya S and Shibasaki R 2001 National spatial crop yield simulation using GIS-based crop production model; Ecol. Model. 136(2) 113-129.

Pruski F F and Nearing M A 2002 Runoff and soil-loss responses to changes in precipitation: A computer simulation study; J. Soil Water Conserv. 57(1) 7-16.

Raje D and Mujumdar P P 2011 A comparison of three methods for downscaling daily precipitation in the Punjab region; Hydrol. Process. 25(23) 3575-3589.

Renard K D, Foster G R, Weesies G A and Porter J P 1991 RUSLE - Revised Universal Soil Loss Equation; J. Soil Water Conserv. 46(1) 30-33. 
Renard K G, Foster G R, Weesies G A, McCool D K and Yoder D C 1997 Predicting soil erosion by water: A guide to conservation planning with the Revised Universal Soil Loss Equation (RUSLE); USDA Handbook, 703, U.S. Department of Agriculture, Washington, DC.

Reusing M, Schneider T and Ammer U 2000 Modeling soil erosion rates in the Ethiopian Highlands by integration of high resolution MOMS-02/D2-stereo-data in a GIS; Int. J. Remote Sens. 21(9) 1885-1896.

Risse L M, Nearing M A, Nicks A D and Laflen J M 1993 Error assessment in the universal soil loss equation; Soil Sci. Soc. Am. J. 57 825-833.

Routschek A, Schmidt J and Kreienkamp F 2014a Impact of climate change on soil erosion - A high-resolution projection on catchment scale until 2100 in Saxony/Germany; Catena 121 99-109.

Routschek A, Schmidt J, Enke W and Deutschlaender T 2014b Future soil erosion risk - Results of GIS-based model simulations for a catchment in Saxony/Germany; Geomorphology 206 299-306.

Segura C, Sun G, McNulty S and Zhang Y 2014 Potential impacts of climate change on soil erosion vulnerability across the conterminous United States; J. Soil Water Conserv. 69(2) 171-181.

Sharma P D, Goel A K and Minhas R S 1991 Water and sediment yields into the Sutlej river from the high Himalaya; Mt. Res. Dev. 11(2) 87-100.

Sheldrick B H and Wang C 1993 Particle size distribution; In: Soil Sampling and Methods of Analysis (ed.) Carter M R; Canadian Society of Soil Science, Lewis Publishers. Ann Arbor, pp. 499-511.

Shiono T, Ogawa S, Miyamoto T and Kameyama K 2013 Expected impacts of climate change on rainfall erosivity of farmlands in Japan; Ecol. Eng. 61 678-689.

Singh G, Babu R and Chandra S 1981 Soil loss prediction research in India; Tech. Bull. T-12/D-9, Central Soil and Water Conservation Research and Training Institute, Dehradun, India.

Sun G E, McNulty S G, Moore J, Bunch C and Ni J 2002 Potential impacts of climate change on rainfall erosivity and water availability in China in the next 100 years; International Soil Conservation Conference, Beijing, China.

SWCS 2003 Conservation implications of climate change: Soil erosion and runoff from cropland; A report from the Soil and Water Conservation Society, Soil and Water Conservation Society, Ankeny, Iowa.

Thiam A K 2003 The causes and spatial pattern of land degradation risk in southern Mauritania using multitemporal AVHRR-NDVI imagery and field data; Land Degrad. Dev. 14(1) 133-142.

Tiwari A K, Risse L M and Nearing M 2000 Evaluation of WEPP and its comparison with USLE and RUSLE; Trans. ASAE 43 1129-1135.
Trenberth K E 2011 Changes in precipitation with climate change; Clim. Res. 47(1) 123.

Van der Knijff J M, Jones R J A and Montanarella L 2000 Soil erosion risk assessment in Europe; EUR 19044 EN, Office for Official Publications of the European Communities, Luxembourg, 34p.

Van Rompaey A J, Verstraeten G, Van Oost K, Govers G and Poesen J 2001 Modelling mean annual sediment yield using a distributed approach; Earth Surf. Proc. Land. 26(11) 1221-1236.

Wilby R L 2004 Guidelines for Use of Climate Scenarios Developed from Statistical Downscaling Methods; IPCC Task Group on Data and Scenario Support for Impact and Climate Analysis (TGICA).

Wischmeier W H and Smith D D 1978 Predicting rainfall erosion losses: A guide to conservation planning; USDA Handbook 537.

Wurbs D and Steininger M 2011 Effects of climate change on the soil studies on soil erosion by water; Environmental Research Plan of the Federal Ministry for the Environment, Nature Conservation and Reactor Safety 370871 205, UBA-FB 001463.

Yang D, Kanae S, Oki T, Koike T and Musiake K 2003 Global potential soil erosion with reference to land use and climate changes; Hydrol. Process. 17 2913-2928.

Zhang X C and Liu W Z 2005 Simulating potential response of hydrology, soil erosion, and crop productivity to climate change in Changwu tableland region on the Loess Plateau of China; Agr. Forest Meteorol. 131(3-4) 127142.

Zhang G H, Nearing M and Liu B Y 2005 Potential effects of climate change on rainfall erosivity in the Yellow River basin of China; Trans. ASAE 48(2) 511-517.

Zhang J X, Chang K T and Wu J Q 2008 Effects of DEM resolution and source on soil erosion modelling: A case study using the WEPP model; Int. J. Geogr. Inf. Sci. 22 925-942.

Zhang Y G, Nearing M A, Zhang X C, Xie Y and Wei H 2010 Projected rainfall erosivity changes under climate change from multimodel and multiscenario projections in northeast China; J. Hydrol. 384(1) 97-106.

Zhang Y, Hernandez M, Anson E, Nearing M A, Wei H, Stone J J and Heilman P 2012 Modeling climate change effects on runoff and soil erosion in southeastern Arizona rangelands and implications for mitigation with conservation practices; J. Soil Water Conserv. 67(5) 390-405.

Zhang F, Li W and Mann M E 2016 Scale-dependent regional climate predictability over North America inferred from CMIP3 and CMIP5 ensemble simulations; Adv. Atmos. Sci. 33(8) 905-918.

Zhou P, Luukkanen O, Tokola T and Nieminen J 2008 Effect of vegetation cover on soil erosion in a mountainous watershed; Catena 75(3) 319-325. 